\title{
The Union Pacific/Southern Pacific Rail Merger: A Retrospective on Merger Benefits
}

\author{
DENIS A. BREEN * \\ Bureau of Economics, Federal Trade Commission
}

\begin{abstract}
This retrospective case study of merger efficiencies focuses on the 1996 merger of two large, U.S. rail networks. Information on the public record permits some evaluation of pre-merger efficiency claims, and the weighing of those claims against regulatory and antitrust standards. Access to additional public and non-public information also permits at least a preliminary determination that a number of the claimed efficiencies were plausibly merger-specific and actually realized post-merger. This is contrary to skepticism expressed about merger efficiency claims, both generally and with respect to this particular rail merger, and thereby illustrates the value of doing retrospective studies of merger outcomes.
\end{abstract}

\section{Introduction}

\section{$1.1 \quad$ Background}

Rail mergers have the potential to generate benefits and costs from a social welfare perspective. End-to-end (vertical) rail mergers ${ }^{1}$ promote network connectivity with improved routings and expanded single-line service between multiple points, thereby generating demand-side benefits for shippers and cost savings for railroads. Parallel (horizontal) rail mergers $^{2}$ also have the potential to improve routings, and they provide the opportunity to eliminate redundancies in rail networks and to exploit economies of scale and traffic density. Concurrent with these potential benefits is the potential for rail mergers to impose social costs,

\footnotetext{
* Mailing address: Bureau of Economics, Federal Trade Commission, 600 Pennsylvania Ave., N.W., Washington, D.C. 20580. E-mail: dbreen@ftc.gov The views expressed in this article are those of the author and do not necessarily represent the views of the Federal Trade Commission or any individual Commissioner. Helpful comments from Neil Averitt, Leslie Farber, Paul Pautler, Michael Redisch, David Scheffman, Paul Pautler, and anonymous referees are appreciated. Credit also goes to Van Brantner and Sandy Lin for research assistance and to Tangela Roundtree for secretarial support.

${ }^{1}$ End-to-end rail mergers refer to combinations of railroads with route networks that are largely in different geographic regions but are connected at points they do have in common.

${ }^{2}$ Parallel mergers refer to combinations of railroads with route networks that overlap geographically and have directly competing routes.
} 
as would be the case, for example, with parallel combinations that reduce rail competition in freight transport markets or rail mergers that seriously disrupt service when network integration proves problematic.

The U.S. rail industry has undergone substantial consolidation over a period of many decades. This trend continued following the Staggers Rail Act regulatory reforms of 1980, with the number of Class I railroads ${ }^{3}$ declining from 40 in 1980 (Harper, 1982, p.219) to 12 in 1994 (General Accounting Office (GAO), 2001, p.1), largely due to mergers. Since then, several relatively large-scale mergers involving industry leaders have occurred: Burlington Northern/Santa Fe (1994), consisting of 35,400 route miles in the western U.S. and Canada; Union Pacific/Southern Pacific (1996), involving 38,654 route miles in the western U.S.; CSX/Norfolk Southern/Conrail (1998), with 23,000 route miles (CSX/Conrail) and 21,800 route miles (NS/Conrail), both in the eastern U.S. and Canada; and Canadian National/Illinois Central (1999), consisting of 18,760 route miles in the midwestern U.S. and Canada. The latter merger was end-to-end in nature, and Burlington Northern/Santa Fe and CSX/Norfolk Southern/Conrail were largely end-to-end mergers, while the Union Pacific/Southern Pacific merger had significant parallel aspects as well as end-to-end components (GAO, 2001, pp.3032). Together these mergers reduced the principal railroads in the western U.S. to Burlington Northern/Santa Fe and Union Pacific/Southern Pacific and in the eastern U.S. to CSX/Conrail and Norfolk Southern/Conrail.

To a significant extent, this industry consolidation via merger reflects a much needed restructuring and rationalization of a regulated industry that was Balkanized and suffering from excess capacity. As GAO has concluded, "[r]ailroads have consolidated largely to reduce costs and increase efficiency and competitiveness" (GAO, 2001, p.1). Nevertheless, the shrinking number of railroads has also raised concerns about a perceived loss of competition and the inability of rail managers to integrate large networks, and critics have become more skeptical of claimed merger benefits. From this perspective, the Union Pacific/Southern Pacific mega-merger examined here, with its significant horizontal overlaps and reported post-merger service problems, became a favorite target of critics. Moreover, these concerns and skepticism are reflected in the Surface Transportation Board's (hereafter STB or Board) - prior to 1996 the Interstate Commerce Commission (ICC) - decision in 2000 to impose a moratorium on mergers involving Class I railroads following a merger proposal by Burlington Northern Santa Fe and Canadian National to create what would have been the first transcontinental railroad in North America. The Board eventually lifted the moratorium but only after adopting stricter merger guidelines that impose heavier burdens on applicants to demonstrate their proposed mergers are in the public interest.

\subsection{The Union Pacific/Southern Pacific merger proposal}

The merger proposed by the Union Pacific Railroad Co. (UP) and the Southern Pacific Transportation Co. (SP) in 1995 would combine two of the three largest railroads in the West and create the largest railroad in the country. UP urged the ICC/STB to approve the merger, claiming that it would generate substantial cost reductions and service improvements and thereby strengthen rail competition in the West. UP viewed the merger as an opportunity to

\footnotetext{
${ }^{3}$ In the mid-1990s, the operating revenue level for designation as a Class I railroad was approximately $\$ 250$ million.
} 
rehabilitate SP, which UP and many others considered an ailing firm with diminishing competitive effectiveness. Many SP shippers supported the merger.

The Department of Justice (DOJ), by contrast, contended that the two rail networks contained extensive stretches of parallel track, including the lines from south Texas through Houston to Memphis, St. Louis, and Chicago; the lines from Houston to New Orleans and San Antonio; and the Central Corridor. ${ }^{4}$ According to Kwoka and White (2004, p.31), the combination of the two railroads would reduce to two ("3-to-2 traffic") or sometimes one ("2to-1 traffic") the number of railroads serving hundreds, and perhaps thousands, of shippers throughout the West. ${ }^{5}$ DOJ $(1996$, p. 1) took the position that the merger proposal would result in "overwhelming competitive harm" in a large number of markets as the combined railroad exercised market power unilaterally or in the form of coordinated behavior with other carriers. Other merger protestants included shippers and shipper organizations, and various railroads. The STB also received submissions from other federal agencies, including the U.S. Department of Transportation (DOT), and from state and local agencies, and labor organizations. Merger opponents considered the proposed remedy to competitive problems involving trackage rights ${ }^{6}$ - to be inadequate. They recommended instead either rejection of the merger application or else conditioning its approval on the full divestiture of rail lines to other railroads where competition was threatened. DOJ and others, as reported in Kwoka and White (2004), and White (2002), also considered many of the efficiencies claimed for the merger to be overstated, or not recognizable as public benefits, or else achievable through alternative means. Kwoka and White also note that certain parties took issue with claims of SP's deteriorating financial condition and competitive effectiveness.

UP acknowledged the horizontal overlaps between it and SP and sought to resolve competitive concerns regarding 2-to-1 shippers by entering into an extensive trackage rights agreement with the Burlington Northern and Santa Fe Railway (BN/SF), the other large railroad in the West. This involved almost 4,000 miles of track (including the 2,100 Denver-toOakland segment of the Central Corridor). UP also agreed to divest another few hundred miles of track to BN/SF. Merger applicants did not propose a fix for 3-to-2 shippers, contending for various reasons that coordinated or cooperative behavior even with as few as two railroads would be difficult.

In its decision of August 6, 1996 (STB, 1996), the STB concluded that on balance the proposed merger would be in the public interest. ${ }^{7}$ The Board found that the BN/SF trackage

\footnotetext{
${ }^{4}$ The Central Corridor was described as an area running from St. Louis to Oakland via Denver, Salt Lake City, and Reno. See DOJ (1996, p.2).

${ }^{5}$ Kwoka and White participated in the ICC/STB merger proceeding, filing comments on behalf of merger opponents Dow Chemical Company and the Kansas City Southern Railway Company, respectively.

${ }^{6}$ These are rights that one railroad (tenant) secures from another railroad (landlord) to move freight over the landlord's lines using the tenant's own locomotives, cars, and crews. The tenant pays a per car and mileage fee to the landlord. As a merger remedy, these rights are imposed by the STB in an effort to restore competition where it otherwise would be threatened by the merger.

${ }^{7}$ Unlike antitrust agencies, the STB must formally approve mergers and in so doing uses a public interest standard that involves a broader balancing of public benefits (service improvements and efficiencies) with any competitive harm. White (2002, pp.163-164) contends that the ICC/STB historically has been more inclined than the antitrust agencies to accept efficiency claims, and that there has been a strong tendency for the ICC/STB to approve rail merger applications. Likewise, Massa (1997, p.415) has noted the tendency for the ICC and STB to approve rail merger applications.
} 
rights for 2-to-1 traffic would be an adequate remedy for potential competitive problems and that there would be important service improvements and efficiencies flowing from the merger. As Kolasky (2004, p.6) characterizes the merger approval, the STB sought to preserve potential efficiencies across the combined networks of the two railroads by using trackage rights, rather than rail-line divestitures, to address competitive concerns on specific routes. A major benefit of the merger, according to the Board, was that it would permit the financially weak SP to become part of a large, financially healthy rail system and thereby be in a position to sustain efficient operations and maintain a viable level of investment in its plant. A revitalized UP/SP in turn would be better positioned to compete with the newly merged, more efficient BN/SF, to the benefit of shippers in the West. The STB's assessment of competitive issues, efficiency claims, and SP's financial condition is generally accepted in a retrospective financial analysis of the merger (Conant, 2004).

The Board thought that the proposed alternative remedy for potential competitive problems - rail-line divestitures - would be overreaching and would impose a greater burden than monitoring the trackage rights agreement. Regarding 3-to-2 traffic in particular, the STB concluded that not taking action here was consistent with its previous rail merger decisions, which were based on the Board's experience that two railroads were sufficient to provide competition. The Board did announce, as a further condition for merger approval, oversight for five years to determine whether the conditions it imposed had effectively addressed the competitive problems they were intended to remedy.

This article has two main purposes. One is to evaluate the efficiencies prospectively claimed for this merger against relevant regulatory (and similar antitrust) standards and economic principles. Because the merger had both end-to-end and parallel components, it permits an examination of a wide range of claimed efficiencies for this (and perhaps other) network industries. The second purpose is to assess, to the extent permitted by available evidence, whether the claimed merger efficiencies were realized. This exercise can be undertaken because the merger was approved (with conditions) by the STB and consummated, despite significant opposition. As a retrospective case study, the UP/SP merger provides an unusual opportunity to examine the efficiencies aspect of merger analysis because post-merger evidence on actual efficiency outcomes can be compared to detailed information on efficiency claims. Such a comparison may be instructive for rail merger policy and merger policy more generally because there is significant overlap between regulatory and antitrust standards for the treatment of those claims, particularly regarding the extent to which such efficiencies are considered to be specific to the merger. Given the merger's significant horizontal overlaps, which can characterize mergers in other industries as well, it is especially interesting to see if substantial efficiencies were realized as an offset to heightened competitive concerns. The efficiency analysis undertaken here seems relevant for merger enforcement policy because of the skepticism that generally exists about merger-related efficiency claims and their realization. See, for example, Conrath and Widnell (1999), for criticisms from the antitrust perspective.

The article does not examine the nature and extent of any anticompetitive effects associated with the UP/SP merger. Therefore, it does not attempt to compare merger benefits with merger costs as part of an overall welfare analysis, although it does consider whether post-merger rate trends are consistent with efficiencies being realized. Section 2 organizes and describes the merger benefits claimed in the merger application. Section 3 examines the STB's 
review of the claimed benefits, including its consideration of arguments made by the merger's opponents, and assesses the magnitude of the claimed efficiencies and whether they are public rather than private in nature, fairly attributable to the merger, not reasonably achievable through other means less likely to raise competitive concerns, and verifiable. All information cited in Sections 2 and 3 was obtained from public sources. Section 4 reviews available evidence from public and certain normally non-public sources to determine whether the merger efficiencies were actually realized to the extent and in the form claimed.

\section{Benefits claimed in merger application}

\subsection{Potential for merger benefits}

The maps on the next two pages show how the UP and SP route networks would fit together as a result of the proposed merger. The two route networks were in the western U.S. and overlapped to a significant extent, with many parallel route segments (for example, OaklandDenver, Houston-New Orleans, San Antonio-Chicago). These horizontal overlaps and the many common service points suggested the possibility of duplicative facilities, and created a potential for cost savings and service improvements through consolidation and integration. ${ }^{8}$ In addition, the two route networks were complementary in nature, with SP filling gaps in UP's system (for example, between TX and CA) and UP filling gaps in SP's system (for example, between the Pacific Northwest and the Midwest). This created the potential for improved routings (for example, combining segments of each railroad to create more direct routes) and single-line service ${ }^{9}$ to more points in the West, both of which appeal to shippers.

The merger benefits, highlighted by UP and SP in their merger application to the ICC, included both quantified and unquantified elements. Both were supported by verified statements from in-house officials and outside consultants. As discussed below, quantified benefits included - in declining order of importance - merger efficiencies and cost savings (total operating benefits), shipper logistics savings, and net revenue (traffic) gains.

\footnotetext{
${ }^{8}$ Grimm and Plaistow (1999, p.74) characterize the UP/SP merger as having "unprecedented parallel effects", in contrast to the largely end-to-end rail mergers from the early 1980s up to the mid-1990s. Similarly, GAO (2001, p.30) characterizes the UP/SP merger as having "significant parallel components", as compared to other rail mergers during the second half of the 1990s.

${ }^{9}$ Single-line service occurs when a shipper's freight moves from origin to destination over the tracks of one railroad, thereby avoiding the cost and delay associated with interchange of freight cars between railroads.
} 


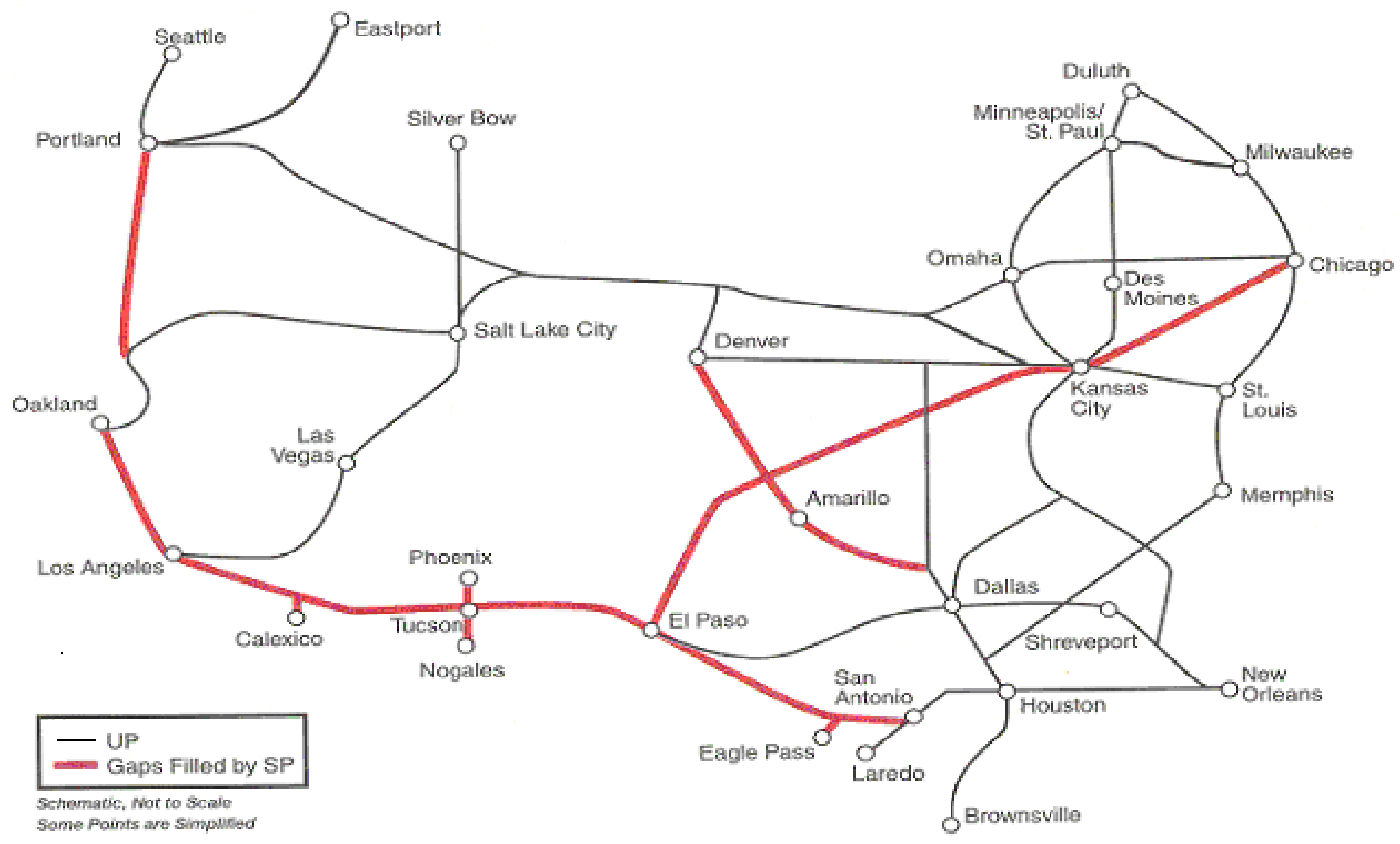

Figure 1: Southern Pacific fills gaps in the Union Pacific system

Source: UP/SP-24 (1995b, p.10). 


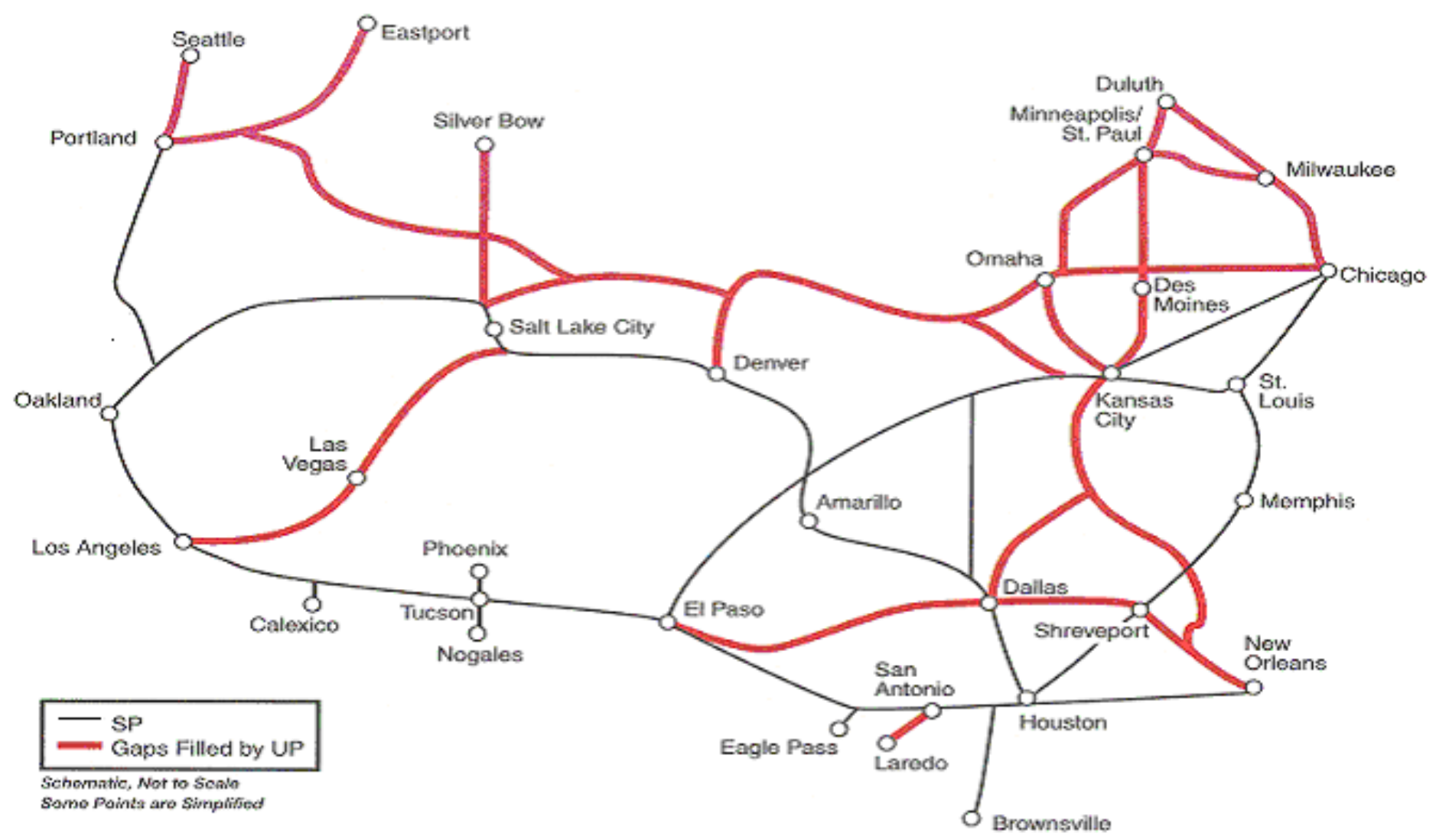

Figure 2: Union Pacific fills gaps in the Southern Pacific system

Source: UP/SP-24 (1995b, p.11). 
Unquantified benefits included expanded single-line service, more efficient routings (for example, shorter routes, directional operation), and increased capacity and capital investment.

\subsection{Magnitudes of quantified benefits}

Table 1 on the next page shows the prospective benefits that the merging railroads quantified in their merger application. For any column in the table, total benefits are the sum of net revenue gains, operating benefits, and shipper logistics savings, less employee relocation costs and labor protection/separation payments. These benefits are linked to the steps to be taken to consolidate and coordinate the operations of the combined railroad, as presented in the 400 page operating plan appearing in Volume 3 of the merger application (UP/SP-24, 1995b). The benefits, and associated costs, are shown for each year of the anticipated fiveyear merger-implementation period. "Annual" (recurring) benefits and costs are distinguished from "one- time" benefits and costs for each year. Examples of the latter include the sale of surplus real estate (benefit) and capital expenditures (cost). The column to the far right projects recurring benefits of $\$ 750.6$ million for a "normal" (typical) year after the two railroads are fully integrated.

The "net revenue gains" row in the table refers to revenue gains to UP/SP from mergerinduced increases in rail traffic, minus revenue reductions from traffic lost to $\mathrm{BN} / \mathrm{SF}$ due to the trackage rights to be granted to BN/SF. The revenue figures are net of the additional cost of handling increased traffic. Labor savings reflect avoided wages, salaries, and benefits, although, as shown further down in the table, adjustment is made for associated employee relocation expenses and labor protection/separation payments. Car utilization reflects savings from more efficient freight car utilization, while communications/computers shows savings from combining communications and information technology systems, less spending on computer and related equipment needed by SP. The operations savings in the table are attributed to more efficient routings; reduced freight-car interchange delay; heavier bridge loadings; line abandonments; savings at points served by both (closure of freight yards, reduced need for vehicles, elimination of various fees and trackage rights charges, etc.) decreased car and track maintenance costs; better control of loss and damage costs; lower fuel costs; and net trackage rights proceeds ( $\$ 47.2$ million) to UP/SP from BN/SF (Draper and Salzman, 1995, p.368). The general/administrative category refers to savings from combining the management and administrative functions of the two railroads. Examples include combining central office functions in fewer buildings, and reduced supply and procurement costs. Thus, the predicted cost savings include reductions in fixed (overhead) as well as variable costs.

The "shipper logistics savings" shown in the table consist of two elements. First are the cost savings to shippers as a result of projected traffic diversions of truckload shipments to UP/SP intermodal (truck/rail) service, due to merger-related service improvements in several traffic corridors, and second are the cost savings to shippers previously using SP for rail carload traffic between selected points in the West, due to savings in time and mileage brought about by the merger. 


\begin{tabular}{|c|c|c|c|c|c|c|c|c|c|c|c|}
\hline & \multicolumn{2}{|c|}{ Year 1} & \multicolumn{2}{|c|}{ Year 2} & \multicolumn{2}{|c|}{ Year 3} & \multicolumn{2}{|c|}{ Year 4} & \multicolumn{2}{|c|}{ Year 5} & \multirow{2}{*}{\begin{tabular}{||l} 
Normal \\
Year
\end{tabular}} \\
\hline & Annual & One-time & Annual & One-time & Annual & One-time & Annual & One-time & Annual & One-time & \\
\hline 「et revenue gains & $\$ 22,814$ & & $\$ 53,232$ & & $\$ 60,836$ & & $\$ 68,441$ & & $\$ 76,045$ & & $\$ 76,045$ \\
\hline Labor savings & 90,585 & & 222,973 & & 255,194 & & 258,390 & & 261,150 & & 261,150 \\
\hline \multicolumn{12}{|l|}{ Non-labor savings } \\
\hline Car utilization & 3,803 & & 8,874 & & 10,142 & & 11,409 & & 12,677 & & 12,677 \\
\hline Communications/computers & $(11,861)$ & $(82,479)$ & 821 & $(27,716)$ & 26,997 & $(2,960)$ & 21,719 & $(1,223)$ & 14,214 & & 14,214 \\
\hline Operations & 46,501 & $(529,947)$ & 102,822 & $(394,951)$ & 130,467 & $(266,539)$ & 144,122 & $(124,960)$ & 157,756 & 9,905 & 157,756 \\
\hline General/administrative & 110,797 & $(139,805)$ & 116,070 & 35,300 & 125,245 & 62,300 & 137,970 & & 137,970 & & 137,970 \\
\hline 'otal operating benefits & 239,825 & $(472,621)$ & 451,560 & $(387,367)$ & 548,045 & $(207,199)$ & 573,611 & $(126,183)$ & 583,767 & 9,905 & 583,767 \\
\hline Employee relocation & & $(26,594)$ & & $(44,742)$ & & $(3,914)$ & & & & & \\
\hline Labor protection/separation & & $(107,411)$ & & $(67,251)$ & & $(11,926)$ & & $(1,726)$ & & & \\
\hline hipper logistics savings & 27,251 & & 63,585 & & 72,669 & & 81,752 & & 90,836 & & 90,836 \\
\hline 'otal benefits & $\$ 289,890$ & $(606,626)$ & 568,377 & $(499,360)$ & 681,549 & $(223,039)$ & 723,804 & $(127,910)$ & 750,648 & 9,905 & 750,648 \\
\hline
\end{tabular}

\section{Table 1: Summary of prospective benefits for UP/SP merger (\$ in thousands)}

Note: Five-year implementation plan. Source: UP/SP-22 (1995a, p.93). 
The merger applicants recognized that operating efficiencies and traffic gains could be realized only by making substantial investments to upgrade and increase the capacity of several SP lines and yards, improving certain UP lines, connecting the railroads' tracks, constructing new intermodal facilities, and improving SP's technological capabilities. UP committed to making these investments in its merger application and operating plan. Many of those projects would be completed during the first year but others were expected to take two years or more. The table was constructed under the assumption that $40 \%$ of the required capital expenditures would be made during the first year of combined operation, $30 \%$ during the second year, $20 \%$ during the third year, and 10\% during the fourth year (Draper and Salzman, 1995, p.364). These up-front capital expenditures meant that one-time costs would be incurred early on and that ongoing benefits from traffic gains and operating efficiencies would start out relatively small, as the table shows, and then increase during the five-year period.

\subsection{Enumeration of unquantified benefits}

\subsubsection{Expanded single-line service and improved routings}

Unquantified benefits featured by merger applicants included service improvements in the form of expanded single-line service and more efficient routes. The generally recognized benefits of single-line service include elimination of freight car interchanges and associated costs and delays, simplification of rate negotiations, and reduced billing errors. These in turn yield better service and allow shippers to expand markets geographically. Two of the numerous examples of expanded single-line service provided by merger applicants, and noted by the STB (1996, pp.564-565) are as follows:

"UP/SP merger will offer a new single-line service between many UP points in the Pacific Northwest (Seattle/Tacoma, Spokane, and a Canadian gateway) and many SP points in CA, AZ, NM, and west Texas, including Mexican gateways.”

“The merger will link UP and SP route networks in TX to UP's routes from Denver to UT, ID, MT, OR, and WA, via SP's route from Ft. Worth to Denver, providing new single-line service for shipments between those regions."

UP and SP also argued that shorter, more direct routes could be assembled by combining key segments of each railroad's lines. These track-mileage reductions implied train-crew and fuel cost savings, and lower rates and faster service for freight traffic on the new routes. Numerous examples were provided in the merger application (UP/SP-22, 1995a, p.29), including the following:

“Los Angeles - Memphis. Merged firm will assemble segments of UP's and SP's lines via El Paso to create the shortest route. SP's route dips into southern TX while UP's route goes as far north as WY and NE. Combining routes would reduce SP's mileage between Los Angeles and Memphis by 283 miles, and reduce UP's mileage by 580 miles."

"Northern California - Midwest. SP has the most direct route between northern CA and Ogden, UT, while UP has the most direct routes from Ogden to the Midwest. Segments will be assembled to create a through route that is shorter than either existing route. A combined UP/SP route between Oakland and Chicago would be 388 miles shorter than SP's route and 189 miles shorter than UP's route."

Other routes could be improved, according to merger applicants, by introducing directional operation. Most of UP's lines and all of SP's lines were single track. The primary cause of train delay on single track is head-on "meets between trains", and adding trains increases meets 
and congestion geometrically. Using a directional system, the number of meets can decrease, and trains can run faster, without adding new track capacity. In the South Central region, for example, one line will be operated northbound to Chicago, St. Louis, and Memphis, and the parallel line will be operated southbound to San Antonio, Houston, and Dallas/Ft. Worth.

\subsubsection{Increased capacity and capital investment}

Also claimed by applicants as a merger benefit, but not included with the quantified benefits, was the approximately $\$ 1.3$ billion that UP/SP planned to spend over four years to upgrade lines and to add new facilities so that merger-related synergies could be realized. These investments are described in the operating plan appearing in Volume 3 of the merger application. Table 2 on the next page lists many of the more significant rail corridor upgrade projects contemplated. Examples of capital expenditures planned for other facilities included $\$ 67.5$ million for the construction of a new intermodal facility in the Inland Empire (eastern Los Angeles basin); \$38.2 million for upgrading and rehabilitating SP's Roseville Yard (northeast of Sacramento); and \$21 million to build a new running repair facility at West Colton (Inland Empire).

\section{Examination of STB review of claimed merger benefits}

\subsection{STB merger review standards}

In reviewing rail merger proposals, the STB is required by statute to apply a public interest standard. Under that standard, it must consider the public benefits of a proposed merger and weigh them against any competitive harm in deciding whether the transaction would be in the public interest. The STB defines public benefits to be efficiency gains that take the form of cost reductions, cost savings, and service improvements (STB, 1996, p.363). Cost reductions occur if a larger rail operation enables the combined railroad to exploit economies of scale, scope, or traffic density commonly found in the rail industry. ${ }^{10}$ Savings arise in fixed and variable costs if consolidation leads, for example, to elimination of interchanges, more efficient movements, reduced overhead, and elimination of duplicative facilities. The STB does not seem to require, but does expect, that these benefits will be passed on to most shippers (to an extent that varies

\footnotetext{
${ }^{10}$ Some have suggested, however, that rail mergers may create combined firms that exceed efficient scale. Kwoka and White (2004) have asserted that the UP/SP merger would create a larger organization which would be more difficult to manage and integration could lead to inefficiencies. Recently, Chapin and Schmidt (1999) undertook data envelopment analysis (DEA) to measure the efficiency of the rail industry. DEA involves application of linear programming techniques to determine production frontiers. Chapin and Schmidt find that while rail mergers (1980-1993) substantially increased technical efficiency in the operation of track networks, they decrease scale efficiencies at the firm level by even more. Their results suggest that many rail mergers result in firms that are larger than an efficient scale. By comparison, a more recent study of rail mergers (for the period 1983-1997, during which rail mergers became ever larger) generally finds significant cost reductions associated with the pure scale effects of combining railroads. See Wilson and Bitzan (2003).
} 


\begin{tabular}{|c|c|c|}
\hline Line segment & Description of upgrade & Capital investment \\
\hline $\begin{array}{l}\text { SP Sunset Route: El } \\
\text { Paso, TX-Los Angeles, CA }\end{array}$ & $\begin{array}{l}\text { Create over } 100 \text { miles of } \\
\text { additional double track }\end{array}$ & \$221.4 millior \\
\hline $\begin{array}{l}\text { SP Golden State Route: } \\
\text { Topeka, KS-El Paso, TX }\end{array}$ & $\begin{array}{l}\text { Install CTC; install } \$ 24.7 \text { million } \\
\text { of welded rail; strengthen bridges; } \\
\text { construct or extend ten sidings }\end{array}$ & $\$ 145.8$ million \\
\hline $\begin{array}{l}\text { UP T\&P Line: Ft. Worth, } \\
\text { TX-El Paso, TX }\end{array}$ & $\begin{array}{l}\text { Install } \$ 74.3 \text { million of welded rail } \\
\text { and ties; extend or build } 18 \\
\text { sidings; other track and signal } \\
\text { work }\end{array}$ & $\$ 125.4$ million \\
\hline $\begin{array}{l}\text { UP OKT Line: Herington, } \\
\text { KS-Ft.Worth, TX }\end{array}$ & $\begin{array}{l}\text { Install } \$ 25.3 \text { million of welded } \\
\text { rail; build, extend or upgrade } 22 \\
\text { sidings; strengthen bridges }\end{array}$ & $\$ 91.5$ millior \\
\hline $\begin{array}{l}\text { UP KP Line: Denver, CO- } \\
\text { Topeka, KS }\end{array}$ & $\begin{array}{l}\text { Install } \$ 49.4 \text { million of welded } \\
\text { rail; build or extend } 15 \text { sidings; } \\
\text { other track and bridge work }\end{array}$ & $\$ 86.6$ million \\
\hline $\begin{array}{l}\text { UP Line: Iowa Jct., LA - } \\
\text { Avondale, LA }\end{array}$ & $\begin{array}{l}\text { Install } \$ 16.4 \text { million of welded } \\
\text { rail; strengthen bridges; build and } \\
\text { extend sidings }\end{array}$ & $\$ 44.3$ millior \\
\hline $\begin{array}{l}\text { Joint Line: Big Sandy, TX- } \\
\text { Ft. Worth, TX }\end{array}$ & $\begin{array}{l}\text { Build or extend sidings and double } \\
\text { track; new crossovers }\end{array}$ & $\$ 25.2$ million \\
\hline $\begin{array}{l}\text { SP Mococo Line: Tracy, } \\
\text { CA-Martinez, CA }\end{array}$ & $\begin{array}{l}\text { Install } \$ 14.7 \text { million of welded } \\
\text { rail; build sidings }\end{array}$ & $\$ 21.0$ millior \\
\hline $\begin{array}{l}\text { Paired Track: Alazon, NV- } \\
\text { Weso, NV }\end{array}$ & $\begin{array}{l}\text { Signal for two-way operation; } \\
\text { install crossovers }\end{array}$ & \$20.5 millior \\
\hline
\end{tabular}

Table 2: Proposed UP/SP corridor upgrades

Source: UP/SP-24 (1995b, p.23). 
with competitive conditions) in the form of reduced rates or improved service (STB, 1996, p.369). ${ }^{11}$ STB scrutiny is important because of the inherent difficulty of forecasting merger benefits and because of the incentive for merger applicants to exaggerate those benefits to win regulatory approval.

The STB's consideration of both competitive harm and efficiency gains is consistent with antitrust policy (DOJ/FTC, 1992, revised 1997) but involves, to a greater extent, the weighing of economic merger benefits against competitive harms. This shows itself in the STB's attention to mitigation by remedial conditions and post-merger oversight. The STB (1996, p.367) contrasts its approach with antitrust review, characterizing the latter as giving less weight to arguments that cost savings justify mergers that otherwise might be viewed as anticompetitive. This suggests that the STB standard more closely resembles a total welfare standard where significant weight is given to producer as well as consumer welfare. In principle, the STB could approve a merger that antitrust authorities might challenge under a consumer welfare standard. As a practical matter, however, the STB's expectation that mergerrelated cost savings be passed on to shippers suggests more of a focus on consumer welfare.

The STB's "public interest" standard is broader than antitrust standards for mergers, allowing for consideration of other factors, including the impact of a merger on employees. Here too, in principle, STB approval or disapproval could diverge from antitrust authority decisions to challenge or not to challenge a merger. At the time of the UP/SP merger application, a longstanding national transportation policy affirmatively encouraged railroad mergers and consolidations that were in the public interest (Commissioner Owen, 1996, p.540). The public interest in this sense included rationalizing railroad infrastructure and eliminating excess capacity, which, among other things, could impart an STB bias in favor of finding public benefits.

Within this general framework, the next two subsections examine the STB's review of the nature and extent of the merger benefits (quantified and unquantified benefits, respectively) claimed by the applicants in this case, and its review of the testimony to the contrary. As explained below, there is significant overlap between STB and antitrust standards for consideration of the extent to which claimed efficiencies must be specific to the merger. This parallel makes the following review instructive for rail merger policy and antitrust merger policy as well. Because the author did not have access to all or better information than that available to the STB, the assessment presented below focuses on the STB's economic reasoning and the apparent thoroughness of its review.

\subsection{Assessment of STB review of quantified benefits}

During the ICC/STB's merger review proceedings, the claimed merger benefits were challenged by certain parties, most notably by DOJ and the Kansas City Southern Railway Company. Most skeptical was DOJ's economic consultant, Laurits Christensen, who, in his verified statement, argued that the quantified benefits attributed to the proposed merger were significantly overstated (Christensen, 1996, p.3). In the view of Christensen and DOJ, the benefits improperly included the following:

\footnotetext{
${ }^{11}$ This expectation appears to be based not on any formal "pass-through analysis" but rather on the STB's general experience since 1980 with rail cost reductions (through merger or otherwise) and related rate trends (STB, 1996, p.370).
} 
(1) Efficiencies which would occur even in the absence of the merger because of favorable productivity trends ${ }^{12}$ in the railroad industry,

(2) Transfers from one party to another that represent private gains rather than social benefits, and

(3) Benefits that UP and SP could achieve (for example, improved equipment utilization, more efficient routing, single-line service) through voluntary contractual arrangements (for example, leasing, trackage rights, joint marketing) as an alternative to merger.

As pointed out in DOJ's accompanying brief (DOJ, 1996, p.43), the discounting of such claimed "benefits" is required by ICC/STB case precedent, by regulations for railroad consolidation, and by economic principles. These positions overlap with Department of Justice and Federal Trade Commission antitrust merger guidelines, which require that claimed efficiencies be "merger-specific". 13

Christensen did not consider many of the methods used to estimate the benefits, or the results, to be well-documented, making it difficult for him to verify or replicate the results. He conceded that the public benefits could be as high as $\$ 505$ million in a normal year (as compared to the applicants' $\$ 750.6$ million figure) but also argued that the benefits could be as low as $\$ 73$ million. The largest claimed benefit, labor cost savings, was scaled down considerably in Christensen's analysis by subtracting out those savings likely to be attributable to the labor productivity gains (estimated to be $2.4 \%$ annually) he expected to occur industrywide, in any event, for the relevant time period. He was inclined to discount the shipper logistics savings because (1) some savings would probably be realized in any event as

\footnotetext{
${ }^{12}$ According to Christensen, the STB's productivity adjustment factor indicated that productivity growth in the rail industry averaged 5.9\% annually for the 1989-1994 period leading up to the UP/SP merger proposal. Christensen also cited a study by Berndt et al., which sought to measure the differential effects of deregulation (1980 Staggers Rail Act) and mergers on cost and productivity for the period 1974-1986. By examining shifts in estimated translog cost functions, they found that mergers during the early post-Staggers period (which were primarily end-to-end) tended to have a cost reducing impact but one of diminishing magnitude over time. Deregulation tended to have a cost reducing impact of increasing magnitude over time. By comparison, the merger-related cost reducing impact tended to be smaller and shorter lived. See Berndt et al. (1993). Such studies provide support for the negative commentary about rail mergers by Massa (1997) and others. A subsequent study, Chapin and Schmidt (1999), includes rail mergers for a longer period (1980-1993), albeit still primarily end-to-end mergers, and also attributes observed efficiency improvements more to deregulation than to mergers. By comparison, Wilson and Bitzan (2003) focus on rail mergers for the period 1983-1997, which include very large mergers (Burlington Northern/Santa Fe and CSX/Norfolk Southern/Conrail, as well as UP/SP) with some, such as UP/SP, having significant parallel components. In that study, merger-related consolidation is found to account for approximately $17 \%$ of the observed reduction in industry costs during the study period, which the authors emphasize is a larger effect than that found in previous research.

${ }^{13}$ The antitrust agencies "will consider only those efficiencies likely to be accomplished with the proposed merger and unlikely to be accomplished in the absence of the proposed merger or another means having comparable anticompetitive effects". Moreover, merger-specific efficiencies must be verifiable to be "cognizable" under antitrust merger guidelines. See DOJ/FTC (1992, revised 1997, p.4). There is less overlap between regulatory and antitrust standards for mergers along other dimensions. For example, the STB appears to recognize fixed as well as variable cost savings but efficiencies are more likely to be considered cognizable under DOJ/FTC merger guidelines if they represent marginal cost reductions. See DOJ/FTC (1992, revised 1997, p.4). See also Kolasky and Dick (2003) on efficiencies under the antitrust merger guidelines.
} 
industry-wide productivity gains occur, (2) the underlying traffic diversion models were not well documented, and (3) the diversion estimates reflected a subjective "consensus" opinion. ${ }^{14}$ Christensen criticized the inclusion of net revenue gains, trackage rights proceeds, and procurement savings because, in his view, these were transfers generating private but not social benefits. He also did not consider the merger to be necessary for achieving efficiencies in the areas of operation, general and administrative, communications/computers, and freight car utilization.

The STB was influenced by these arguments. Its review of the claimed benefits, and its consideration of opposing arguments from DOJ/Christensen and others, led to the downward adjustment of public benefits shown in Table 3 on the next page. That is, applicants' claimed benefits for a normal year were scaled down from $\$ 750.6$ million to $\$ 627.4$ million, a $16.4 \%$ reduction. Likewise, the STB's figure for operating benefits, $\$ 534.3$ million, was lower (by $8.5 \%$ ) than the claimed operating benefits of $\$ 583.8$ million. The restated $\$ 534.3$ million in operating benefits was achievable, according to the Board (STB, 1996, p.376), because:

"UP/SP will: (a) streamline and consolidate operations at major common terminals; (b) combine terminal and station facilities at a number of common points; (c) establish new blocks and new trains to improve service and efficiency; and (d) pursue numerous coordinations and consolidations of transportation, mechanical, engineering, information, purchasing, customer service, and other operating and marketing functions and activities. In addition, traffic will be handled more efficiently, in many instances by using shorter routes. The combined car fleet will be managed on a coordinated basis to reduce empty movements and improve equipment use. Economies will also be achieved in applicant carriers' administrative functions by combining SP and UP departments to permit more efficient use of existing personnel and reduce overall staff and office space."

The $\$ 534.3$ million in efficiency gains, if expressed as a percent of total operating expenses, would be $6.2 \%$ for a normal year. The STB concluded from the record that gains of this magnitude, ceteris paribus, would enable the combined railroad to lower its operating ratio - operating expenses as a percent of operating revenues - by at least four points. ${ }^{15}$

\footnotetext{
${ }^{14}$ Merger applicants used two transportation consulting firms, Transmode Consultants and Reebie Associates, to project traffic diversions of truckload shipments to UP/SP intermodal (truck/rail) service, due to mergerrelated service improvements in several traffic corridors, and to estimate associated logistics cost savings to shippers. Transmode Consultants did this with a computer-based "logistics cost diversion model" and data from the North American Truck Survey (compiled by the Association of American Railroads). Reebie Associates used a different methodology and data source, which led to somewhat different results. The two consulting firms conferred to reach agreement on "best estimates" of traffic diversion. Transmode Consultants separately used a variation of its logistics cost diversion model to estimate costs savings (due to mergerrelated savings in time and mileage) to UP/SP shippers presently using SP for rail carload traffic between selected points in the West. See Ainsworth (1995) for Reebie Associates and Roberts (1995) for Transmode Consultants.

${ }^{15}$ See STB (1996, p.376 and Appendix F: Financial Ratios). The operating ratio is a frequently used efficiency measure in the railroad industry, despite obvious shortcomings. In the pre-merger year of 1995, UP's operating ratio was $79.2 \%$ while SP's was $96.7 \%$. The STB's Appendix F table shows the combined railroad's operating ratio falling from $82.9 \%$ to $78.9 \%$ by the fifth year of merger implementation.
} 


\begin{tabular}{|c|c|}
\hline Benefit category & Savings \\
\hline \multicolumn{2}{|l|}{ Operating benefits } \\
\hline Labor savings & $\$ 261.2$ \\
\hline \multicolumn{2}{|l|}{ Non-labor savings } \\
\hline Car use & 12.7 \\
\hline Communications/computers & 14.2 \\
\hline Operations & 116.5 \\
\hline General/administrative & 129.7 \\
\hline Subtotal (operating benefits) & 534.3 \\
\hline$\underline{\text { Shipper logistics savings }}$ & 93.1 \\
\hline$\underline{\text { Total quantifiable benefits }}$ & $\$ 627.4$ \\
\hline
\end{tabular}

Table 3: STB restatement of projected annual efficiencies and cost savings for normal year ( $\$$ in millions)

Source: STB (1996, p.376).

The STB's assessment of these issues appears to have been generally sound, with certain exceptions. The agency appropriately excluded $\$ 47.2$ million in net trackage rights proceeds from BN/SF (included in operations savings) because the largest portion of it appeared to be a transfer. It also appropriately excluded the $\$ 76$ million in net revenue gains because traffic diversions, as such, are not public benefits. The cost savings and service improvements that lead to traffic diversions are accounted for elsewhere. More difficult to assess is the STB's rejection of Christensen's argument that $\$ 102.9$ million in procurement savings (from combined purchases) is a transfer from suppliers to UP/SP, and not reflective of efficiencies achieved by suppliers. Christensen had the better of the argument to the extent such savings merely reflect UP/SP's combined purchasing power. Yet, it does seem that combining procurement functions had the potential to save resources for UP/SP, and that volume discounts could, to some extent, reflect real economies for suppliers.

The STB found that claimed efficiency benefits - particularly labor savings - were not based on continuing productivity improvements in the substantially deregulated environment following enactment of the 1980 Staggers Rail Act, ${ }^{16}$ as DOJ/Christensen had argued, but on particular savings made possible by implementation of the post-merger operating plan. Christensen admitted he had not examined the operating plan. ${ }^{17}$ It does not appear, however,

\footnotetext{
${ }^{16}$ For an examination of productivity improvements and cost reductions that were facilitated by Staggersrelated regulatory reforms, see Ellig (2002).

17 The STB was also critical of the method Christensen used to scale down the labor savings estimate because
} 
that the STB otherwise attempted to verify the labor savings results, so one can reasonably question whether they would be as high as the \$261 million in a normal year claimed by the applicants and accepted by the STB.

The Board also considered the shipper logistics savings to be merger-related, rather than reflective of ongoing productivity gains for the entire industry, as Christensen had urged. The underlying traffic diversion model employed by Transmode Consultants to generate the savings estimates was explained by Transmode to have been developed for the Federal Railroad Administration, and widely used. Nevertheless, Christensen was correct in arguing that its use here was not well-documented in the merger application and, as a result, its findings and the consensus estimates were difficult to verify. ${ }^{18}$ Moreover, the shipper logistics savings of \$93.1 million shown in the STB's restatement appears to double-count part of the cost savings reported under total operating benefits. That is, cost savings from single-line service and more efficient routes are counted as operating benefits to the combined railroad, and counted again (at least for the subset of traffic corridors examined in the diversion analysis) as savings to shippers.

As for DOJ/Christensen's argument that some or all of the benefits in operations, general and administrative, communications/computers, and car utilization could be achieved through arrangements short of merger, the STB responded that it and the Interstate Commerce Commission historically were inclined to show deference to rail management as to how efficiencies can best be achieved. The Board cited earlier decisions where applicants explored at length non-merger alternatives suggested by DOJ, and the Board concluded there were Apractical, legal, and competitive problems which would substantially lessen the effectiveness of such arrangements" (STB, 1996, p.379). The Board found in these cases that unified management resulting from a merger was necessary to attain significant operating economies projected in the merger applications, and the STB seemed to have a reasonable basis for its decisions in these matters. ${ }^{19}$ The Board also noted that voluntary arrangements short of merger would not confer the antitrust immunity that an STB-approved merger provides; which is

that estimate was attributed to observed labor productivity gains in the industry for 1989-94. This was a period of time, however, when the positive effects on productivity of several rail mergers, as well as other industrywide innovations, were likely to have occurred.

${ }^{18}$ The Reebie Associates methodology for estimating traffic diversion and shipper cost savings is even less apparent from its description in the merger application.

${ }^{19}$ UP argued that cooperation works best when two railroads are "similarly motivated and are prepared to commit equal resources - preconditions that rarely apply in practice". UP illustrates problems it had encountered, attempting to enter into cooperative arrangements with SP, with an example of failed efforts over the years to rationalize their train operations between Salt Lake City and Ogden UT, a congested segment of each railroad's route between the Midwest and West Coast. The consequences for each railroad were delay, extra fuel cost, and additional miles for each train traveling the route. The inability to reach an agreement was attributed to the cost of resolving labor issues; its impact on the relative competitiveness of the two rival carriers; UP's doubts about SP's willingness to maintain and upgrade its tracks on the route; and difficult compensation issues because the two routes were of different length and had different maintenance requirements. See UP/SP-24 (1995b, pp.9-15). Nevertheless, Christensen (1996, pp.31-32) took the view that arrangements short of merger generally were feasible, suggesting somewhat implausibly, for example, that it would be a simple matter for SP to gain access to UP's superior Transportation Communications System software by contracting with UP, its rival, for it. 
particularly important for a UP/SP-type merger where the "core operations of their competing systems" need to be coordinated (STB, 1996, p.379).

\subsection{Assessment of STB review of unquantified benefits}

Turning to the unquantified benefits, the STB concluded its review of the record by stating that the merger applicants had provided evidence of Aunprecedented opportunities for improved routings and new single-line routes" (STB, 1996, p.381). As in past rail merger cases, the STB placed substantial weight on evidence of improved routes, and consistently recognized singleline service to be a public benefit.

Christensen had argued that there are a number of ways railroads can cooperate for mutual gain that do not involve merging. Examples given include the grant of trackage rights, runthrough trains, ${ }^{20}$ and the leasing of idle cars to railroads with car shortages. ${ }^{21}$ Thus, some of the claimed benefits could be achieved, according to Christensen, by means short of merger. The STB responded, it seems appropriately given the practical, legal and competitive problems it had experienced with non-merger alternatives, that it is implausible that coordination on this scale could be achieved through voluntary trackage rights and other cooperative arrangements, and not require the impetus of merger. ${ }^{22}$

While the Board's treatment of expanded single-line service and more efficient routes as unquantified benefits suggests they should be considered in addition to quantified benefits, they are more properly regarded as a restatement of cost savings for the combined railroad, which are counted under operating benefits. That is, merger-related cost savings are passed on to shippers to some extent but the savings to shippers are not quantified by merger applicants, except, as discussed above, for those captured in the shipper logistics savings.

Other unquantified benefits highlighted by the STB include capital expenditures to be undertaken by the combined railroad to improve service and enhance competitive effectiveness. The Board considered them to be merger-related investments, as the details of the merger application operating plan suggest. Many of the investments were intended to

\footnotetext{
${ }^{20}$ This is an arrangement that allows a railroad to assemble a train of cars in a manner that avoids or reduces intermediate switching by another railroad in an interline movement. The locomotive and the cars are interchanged between the two railroads.

${ }^{21}$ Likewise, Massa (1997, p.432) cites a number of examples, since the early 1990s, of voluntary trackage or hauling arrangements, and joint marketing agreements, that purportedly were implemented in the absence of merger.

${ }^{22}$ There is an apparent inconsistency, as noted for example by Massa (1997, pp.440-441) in the STB finding non-merger arrangements such as trackage rights to be infeasible, and the Board accepting trackage rights as a workable merger remedy. One significant and obvious difference, however, is that trackage rights as a merger remedy would be negotiated by the parties, because they are mandated, and that the STB would have continuing oversight. In addition, the STB took steps to resolve predictable problems associated with trackage rights agreements in this context. As one example, the STB had the merger applicants and BN/SF reach a written agreement on a protocol to prevent discrimination by UP/SP train dispatchers against BN/SF trains in gaining access to UP/SP's rail lines. See STB (1996, pp.403-404) and Conant (2004, p.126). The STB also had in place procedures for setting compensation rates for the trackage rights to ensure they were adequate as reimbursement to an owner railroad such as UP/SP but would not preclude a tenant railroad such as BN/SF from being an effective competitor (STB, 1996, pp.413-417). In general, the STB noted that trackage rights had been widely used and time tested in rail merger proceedings (STB, 1996, p.371). While these differences resolve some of the apparent inconsistency, they also suggest that trackage rights in the merger context may not be free from regulatory burden or error.
} 
update what the STB characterized as SP's inadequate rail lines and related structures and facilities. The Board concluded, and the record seems to support, that SP could not raise the capital for this task on its own, and UP, not unreasonably, would lack the motivation to provide such capital through any arrangement short of merger. ${ }^{23}$

While the projected capital expenditures appear to be merger related, they should not in and of themselves be regarded as public benefits. If undertaken as planned, they could lead to public benefits, properly measured as cost reductions, cost savings and service improvements, but they are the predicate for those benefits. In other words, they should be viewed as costs of achieving the claimed operating benefits, and the merger applicants elsewhere treated them as one-time costs (as explained above with respect to Table 1).

\subsection{Conclusion on claimed merger benefits}

UP can be credited with submitting a merger application that enumerated claimed benefits and made reasonable attempts to quantify them in dollar terms. These claims were further supported by UP's merger implementation and operating plan, also submitted as part of the merger application, which provided a detailed explanation of how and when claimed merger benefits were to be achieved. Also to its credit, UP presented claimed benefits net of the costs incurred to achieve them, including required capital expenditures. ${ }^{24}$ In addition, claimed benefits that were not quantified were, nonetheless, described and itemized.

The STB appropriately considered not only the magnitude of the claimed benefits and support for the amounts claimed, but also whether they were public rather than private in nature, attributable to the merger, and not reasonably achievable through other means less likely to raise competitive concerns. It did not merely rubber stamp all of the benefits claimed by applicants but at the same time it did not mechanically accept the exclusions proposed by DOJ's witness Christensen. ${ }^{25}$ The eventual STB decision suggests that many rail-related efficiency claims can be demonstrated to be merger-specific under regulatory standards and perhaps antitrust standards as well. The Board's exclusion of certain claimed benefits because they appeared to be transfers (private benefits) seems justified, although its decision not to exclude any part of procurement savings from combined purchases, for the same reason, could

\footnotetext{
${ }^{23}$ Funds from internal SP sources or public capital markets were reported to be increasingly difficult to obtain to meet SP's capital shortfall. This is not to suggest some sort of capital market failure but rather that the efficiencies and service improvements for which capital improvements were needed were in areas requiring cooperation between UP and SP to achieve them. The STB found that UP was the only railroad offering to acquire the entire SP system and invest the amounts needed, and UP attributed this willingness to the "unique synergies" it saw flowing from combining the two systems (Yarberry, 1995a, p.260).

${ }^{24}$ This appears to be consistent with practice at the ICC/STB and antitrust agencies at the time although neither the then-applicable railroad consolidation procedures policy statement nor the antitrust merger guidelines were explicit on that point. More recently, the STB has become explicit in requiring that merger applicants calculate "net public benefits" (STB, 2001, p.21) and, similarly, the current antitrust merger guidelines define cognizable efficiencies to be "net of costs produced by the merger or incurred in achieving these efficiencies" (DOJ/FTC, 1992, revised 1997, § 4).

${ }^{25}$ The STB, in fact, was clearly skeptical of Christensen's testimony. It cited his previous testimony on behalf of certain utilities in the BN/SF merger proceeding, where he concluded that there were few quantifiable merger benefits. The Board contended that post-merger experience proved that conclusion to be substantially in error as realized benefits reportedly exceeded even the merger applicants' expectations (STB, 1996, pp.376377).
} 
be questioned. Also questionable was the STB's willingness to accept all of the shipper logistics savings, since some of these seem to double-count savings already listed under operating benefits, and because the method of deriving these savings was not welldocumented.

A substantial part, but probably not all, of the claimed savings - particularly labor cost savings - could properly be attributed to the merger, rather than to expected productivity gains in the industry, and it does not seem that integration by other than ownership, at least at that time, was a reasonable alternative to achieving claimed benefits on the scale contemplated by UP. There does appear to be room for improvement in terms of the STB's efforts to verify the estimates (closer inspection of work sheets, etc.). This leaves open the possibility that some exaggeration by merger applicants may have occurred and, because of a national transportation policy still favorable to rail mergers at the time, may have been allowed by the STB. ${ }^{26}$

Even if one made adjustments for these considerations, however, the properly recognized (or cognizable) public benefits seem to be of substantial magnitude. Moreover, that might be an understatement of benefits because the analysis has compared a post-merger outcome with a pre-merger world. To the extent that SP's assets and service levels would have deteriorated without the merger, the merger may have generated greater benefits than the present analysis implies. In its 1996 merger decision, the STB did find that SP was financially weak, and that its service level was below that offered by competitors, and declining. ${ }^{27}$ As previously noted, the STB concluded that UP was the only buyer to make an offer for the entire SP system.

The STB also examined the unquantified benefits claimed by the merger applicants, and found them to be important public benefits. Unquantified benefits that take the form of expanded single-line service and more efficient routes, however, are the manifestation of the cost savings already accounted for under operating benefits claimed, and those that take the form of capital expenditures may well lead to public benefits but are actually a cost of achieving them.

\footnotetext{
${ }^{26}$ Subsequently, following the CSX/Norfolk Southern/Conrail merger (1998) and the Canadian National/Illinois Central merger (1999) and the submission of the proposal (1999) to merge Canadian National with BN/SF, the STB imposed a 15-month moratorium on rail mergers and adopted a stricter merger policy (STB, 2001b). A stricter policy was warranted, according to the STB, in light of the declining number of large-scale railroads, elimination of the industry's excess capacity, and the significant transitional service problems associated with the recent consolidation of rail networks. An important aspect of the tougher approach, and an implicit admission of room for improvement on the STB's part, is its statement that "we will scrutinize claimed merger benefits more closely" (STB, 2001b, p.17).

${ }^{27}$ DOJ had taken issue with the claim that SP was financially weak, noting, for example, that SP had generated positive cash flow in three of the previous five years. It also thought that SP's competitive effectiveness should not be ruled out because of it service problems. Claims of inferior service and weak and deteriorating financial condition at the time of the merger, however, were further supported by a subsequent UP report. See Gray (2001). See also Conant (2004, p.120), noting that for the years 1982-1995, SP revenue from rail operations had exceeded operating expenses just four times.
} 


\section{$4 \quad$ Evidence on realization of claimed merger benefits}

\subsection{Merger implementation and service disruptions and delays}

The merger was consummated in September 1996, and a multi-stage implementation plan commenced. Months into the merger implementation process, however, press accounts appeared indicating that the UP/SP system was experiencing significant service problems. GAO (2002, pp.5-6) later identified July 1997 as the start of serious service disruptions and shipment delays, and they continued into 1998. Mounting traffic congestion on what was described as the aging rail infrastructure in the Houston area began affecting rail service throughout the western U.S. Service problems were evident across the UP/SP system and took the form of poor transit times and inadequate car supply. In the first annual oversight hearings (STB Oversight, 1997) on the UP/SP merger, the Board characterized these service and safety deficiencies as quite serious and took a number of actions to resolve them. The Board found in STB Oversight (1997) that the service disruptions were caused by a variety of factors including UP efforts to rehabilitate SP's deteriorating infrastructure and establish facilities that would ultimately mean improved service for shippers, and other system integration efforts that had not progressed as they should have. UP acknowledged that difficulty in finalizing labor agreements was delaying implementation of workforce integration, and that installation of a new computerized control network needed to operate the merged system was behind schedule. However, UP also pointed to a number of unrelated events that made service problems worse and that were clearly beyond its control. These ranged from surges in demand for rail transportation and backups in traffic moving to and from Mexico related to rail privatization there, to problems caused by floods and hurricanes. By December 1998, in its second oversight hearings decision (STB Oversight, 1998a), the Board concluded that the UP/SP service situation had improved considerably and was expected to continue to improve.

It is undisputed that serious service problems occurred in the post-merger period. Any merger is likely to encounter at least some integration problems, and integration-related reductions in service reliability should be viewed as a disadvantage of the merger. Moreover, the probability of encountering integration problems is likely to be higher for larger scale mergers where substantial long-term integration efficiencies are claimed. Critics of the UP/SP merger have pointed out that UP had difficulty in absorbing the smaller Chicago and North Western Railway in 1995 - the STB (1996, p.378) admits it was a Arocky experience" - so serious integration problems could be expected for the large-scale UP/SP merger.

While the conventional wisdom appears to be that implementation of the merger plan caused both acute and chronic service problems, ${ }^{28}$ the record suggests that serious disruptions had ended and service was returning to normal levels after a little more than a year. ${ }^{29}$ Admittedly, any costs associated with immediate merger-related service disruptions and shipment delays (that is, costs incurred by UP/SP and those produced for others) should be

\footnotetext{
${ }^{28}$ This view is reflected in the press, in academic work, and in other commentary. See, respectively, (1) Kaplan (1997); (2) Kwoka and White (2004), Conrath and Widnell (1999), White (2002); and (3) Pittman (1998), McFarland (1999).

${ }^{29}$ See, for example, DOT letter dated August 16, 1999, for the 1999 oversight hearings, stating that UP rail service had returned to normal levels. The letter is referenced in STB Oversight (1999, p.16).
} 
given somewhat greater weight in a net present value calculation of merger efficiencies. Such service problems could, in principle, delay or outweigh expected efficiency gains. At least with respect to this merger, however, management shortcomings in anticipating and resolving integration problems may have been just one of several causes of the service problems. The relatively poor condition of the SP infrastructure and unrelated events may have contributed at least as much to the service disruptions, and there is plausibility to the suggestion by the STB that SP would have experienced service problems even absent the merger. While the magnitude of costs related to the service disruptions that were merger-related is unknown, it should be kept in mind that in a net present value calculation they would be viewed as an initial offset to a continuing stream of efficiencies.

\subsection{Overview of realized merger benefits}

The STB's annual oversight hearings (1997-2001) on the UP/SP merger were initially thought to be a valuable source of public information for research on the extent to which claimed benefits are realized. The merger appeared to be an excellent candidate for a retrospective case study and provide an unusual opportunity to track merger efficiencies all the way from those claimed in a merger application to those achieved post-merger. Unfortunately, progress reports on the realization of projected merger benefits were given relatively little attention in the five post-merger oversight proceedings as the STB focused foremost on assessing the adequacy of the conditions it imposed on the merger to address competitive concerns, ${ }^{30}$ and with resolving the 1997-98 service disruptions and delays. What attention was paid to the realization of merger benefits is summarized below.

The Board, in STB Oversight (1998a), noted that while the merger has not proceeded as smoothly as expected, it had produced and would continue to produce benefits to the shipping public. Examples given included expansion in the number of single-line services and shorter routings, better equipment deployment, and reduced switching charges. STB Oversight (1999) discusses the significant progress made in merger implementation during the year. Relying on UP's submission, the STB lists, as examples, the successfully installed Transportation Control System, progress on integration of work forces, and consolidation and improvement of terminals and yards. STB Oversight (2000a)'s discussion of merger benefits highlights UP's progress in making capital improvements to rehabilitate SP. UP planned to spend about $\$ 1.3$ billion over a four year period and reported it was on target since it would spend $\$ 1.25$ billion by the end of 2000. The Board considered it both burdensome and unnecessary to undertake a study requested by the California Public Utilities Commission to determine whether UP achieved all projected merger benefits and whether the realized benefits had been passed on to shippers. It pointed out the absence of shipper testimony to the contrary and cited an STB staff

\footnotetext{
${ }^{30}$ Following the first annual round of oversight hearings, the STB concluded that the record to that point did not reflect any "serious competitive problems". The Board acknowledged, however, it was too early to conclude with any certainty that competition between UP/SP and BN/SF would be vigorous over the longer run. See STB Oversight (1997, p.2). By the fifth and final oversight hearing, the STB concluded more strongly that "overall, the evidence demonstrates that the [trackage rights] conditions we imposed on the UP/SP merger have effectively remedied ... any competitive harm that would otherwise have been associated with that transaction" (STB Oversight, 2001a, p.1).
} 
study finding rate reductions for Western railroads over the years as an indication that efficiency gains were being realized and that many of them were being passed on to shippers.

In the fifth and final oversight proceeding (STB Oversight, 2001a), the STB concurred in UP's assertion that it had achieved the full measure of the merger-related efficiencies predicted and that savings were being passed on to shippers. The public version of the UP submission (UPC-384, 2001c), however, offers only a few examples of expanded single-line service and shorter routes, and its estimate of annual savings of \$690 million from the merger is offered without supporting documentation. Thus, any conclusion that the merging parties substantially achieved the promised service improvements and cost savings must be a preliminary one, to the extent it is based on the public record from the STB's post-merger oversight proceedings.

\subsection{Realization of quantified benefits}

To further document the realization of claimed merger benefits, several additional sources of public and non-public information were consulted. Public sources include UP presentations to financial analysts; merger-related commentary in UP reports to the Securities and Exchange Commission (SEC); and relevant academic research. Public information on post-merger operating ratios and rates was also considered as possible indirect evidence of realized merger benefits. Non-public sources of information include (1) UP's internal tracking report on the realization of merger efficiencies, from a ledger kept for that purpose that was especially relevant for this report, and (2) the confidential version of UP's submission (UPC-384, 2001b) for the STB's 2001 oversight hearings (covering post-merger service improvements, capital expenditures, and UP's rate study). ${ }^{31}$ The non-public documents were provided by attorneys at Covington \& Burling, serving as outside counsel for UP. The attorneys also briefed the author on those documents and were available then and at other times to answer questions about them. These documents were offered voluntarily, but the author is not aware what other relevant information, whether favorable or not to UP, may have existed. ${ }^{32}$

Table 4 on the next page presents the results of an effort by UP to track the realization of merger efficiencies for management purposes, and it shows that substantial ongoing benefits were achieved. ${ }^{33}$ The merger benefits are stated net of the costs of achieving them but do not include any merger-related costs associated with the 1997-98 service problems. The "ongoing savings" line corresponds to "operating benefits" in applicants' Table 1 and STB's Table 3 and the $\$ 679$ million in realized savings in fixed and variable costs exceed the normal-year operating benefits of $\$ 583.8$ million, as claimed by applicants, and restated as $\$ 534.3$ million

\footnotetext{
${ }^{31}$ Confidential submissions in the merger proceedings were available under STB rules to outside counsel and consultants to parties to the proceedings.

${ }^{32}$ Public and non-public information on customer (shipper) satisfaction was also obtained and examined as possible indirect evidence of realized merger benefits. Ceteris paribus, if savings were being realized and passed on to shippers in the form of rate reductions and service improvements, one would expect shipper satisfaction to be greater in the post-merger period. Unfortunately, available evidence on customer satisfaction in the post-merger period is mixed and not particularly reliable or informative. Objective service metrics are not available for the relevant time period (one that straddles the 1997-98 period of service disruptions and delays), surveys indicating customer dissatisfaction appear to be biased, and surveys showing customer satisfaction are not especially informative.

${ }^{33}$ The author did not have direct access to the ledger being referenced to support the Table 4 merger benefits (and costs). This precluded, for example, presentation of the Table 4 results at more disaggregated levels.
} 
by the STB. The outside attorneys represent that UP management sought post-merger progress reports on merger-specific savings to compare to its multi-stage merger implementation plan. The tracking and reporting were done by the Financial Analysis Group in UP's Finance Department and the results were critically reviewed by senior management. Department heads, who assisted in the identification and compilation of merger benefits, reportedly had little

\begin{tabular}{|c|c|c|c|c|c|}
\hline & 1997 & 1998 & 1999 & 2000 & 2001 \\
\hline Material/contract prices & $\$ 31$ & $\$ 48$ & $\$ 47$ & $\$ 49$ & $\$ 49$ \\
\hline Operational savings & 60 & 167 & 196 & 247 & 268 \\
\hline Labor savings & 72 & 142 & 171 & 254 & 257 \\
\hline All other - net of costs & 79 & 82 & 105 & 105 & 105 \\
\hline Ongoing savings - net & 242 & 439 & 519 & 655 & 679 \\
\hline Commodity revenue - est. & $\mathrm{B}$ & B & $\mathrm{B}$ & 90 & 150 \\
\hline Total ongoing benefits & $\$ 242$ & $\$ 439$ & $\$ 519$ & $\$ 745$ & $\$ 829$ \\
\hline
\end{tabular}

Table 4: Merger benefits and costs - ongoing merger benefits ( $\$$ in millions)

Source: Union Pacific document provided to the author by Covington \& Burling.

incentive to overstate them as their budgets normally were reduced by the merger benefit amounts. These considerations give the numbers greater credibility than they would have if they had been generated exclusively for regulatory purposes, such as for presentation during STB's post-merger annual oversight proceedings, ${ }^{34}$ or to impress the author. UP, of course, would have an incentive to report favorable information publicly, in an appropriate format, and it did report a total operating savings figure in the public version of its submission (UPC-384, 2001c) for the STB's final oversight hearing. ${ }^{35}$ At one point, it also reported favorable information about realized merger efficiencies to securities analysts. ${ }^{36}$

\footnotetext{
${ }^{34}$ Consistent with this change in purpose, note that shipper logistics savings do not appear in Table 4 even though they were claimed as a benefit in Table 1 .

${ }^{35}$ According to outside counsel for UP, the operating savings figure of \$679 million in Table 4 for 2001 (current as of October 2000) was updated to \$690 million, as noted above, for UP's July 2001 submission to the STB.

${ }^{36}$ In January 1997, at a meeting in New York, UP told rail industry stock analysts that it expected mergerrelated savings to exceed those quantified in the merger application. As a result, analysts raised their expectations for total operating benefits to \$233 million for 1997. For management purposes, UP then tracked actual savings to see how well the company did each year in meeting the new expectations of the stock
} 
According to outside counsel for UP, the numbers for material/contract prices in Table 4 reflect discounts on fuel and materials, and similar savings on supply/service contracts. (The material/contract price category was included in general/administrative in Table 1.) To the extent the discounts on combined purchases reflect cost savings to suppliers, they are public benefits.

The sources for the operational savings numbers in the table are numerous. Consistent with the merger-related operating plan, they include shorter routes, directional running, reduced interchange of cars between railroads, enhanced car utilization (listed separately in Table 1), combined freight yards and freight car shops, and combined offices and computer systems. ${ }^{37}$ The merger also provided an opportunity to introduce a hub and spoke system for deploying train crews. That is, wherever each railroad had a major terminal, train crews were combined into a single workforce with crews assigned to any spoke as needed, as compared to labor's insistence in the past that crews be dedicated to specific routes. ${ }^{38}$

Labor cost savings, as shown in Table 4, were reportedly achieved in every department, and most of the redundant workforce eliminated involved other than train crews. ${ }^{39}$ (Some of these savings were accounted for under general/administrative in Table 1.) According to 10-K (annual) and 10-Q (quarterly) reports UP submitted to the SEC, the merger implementation plan called for severing 5,200 employees. Its quarterly reports to the SEC reported progress toward that goal, for example, 2,450 severed by the first quarter of 1999, 3,620 severed by the third quarter of 2000, and its annual report for 2001 indicates that it completed elimination of the 5,200 employees.

analysts. As the following non-public table shows, analysts' expectations were not met in 1998, 1999, or 2000, but scaled-down expectations were met in 2001:

\begin{tabular}{|lrrrrr|}
\hline & 1997 & 1998 & 1999 & 2000 & 2001 \\
Stock analysts expectations & 233 & 510 & 680 & 780 & 820 \\
Actual benefits & 242 & 439 & 519 & 745 & 829 \\
\hline
\end{tabular}

Total ongoing benefits (millions of \$)

Source: Union Pacific document provided to the author by Covington \& Burling.

${ }^{37}$ From the ledger used to track merger benefits, outside counsel for UP provided the following examples of operational savings for 2000: \$35 million from elimination of interchanges and improved car utilization; \$18 million from directional operation of trains; $\$ 11.4$ million in reduced fuel consumption form switching to more efficient UP locomotives; and \$43.7 million by eliminating SP's duplicative computer system. (Net trackage right proceeds were disallowed by the STB, for reasons given above, and are excluded from the operational savings reported in Table 4).

${ }^{38}$ UP also cited operational savings (but not dollar amounts) in its periodic reports to the SEC. Its annual report for 1997, for example, mentions the following ongoing elements of integration: (1) introduction of directional operation on parallel tracks in certain corridors, (2) negotiation and implementation of labor agreements to allow more efficient use of train crews in hub and spoke operations, and (3) integration of computer systems. See UPRC (1997, p.3). Its 1998 quarterly reports indicate that UP continued to merge or dispose of redundant facilities, cancel uneconomical and duplicative SP contracts, and dispose of certain rail lines. UP also noted that full implementation of the merger will result in expanded single-line service, shorter routes, faster transit times, better on-time performance, and more efficient traffic flow. See, for example, UPRC (1998, p.11).

${ }^{39}$ From the ledger used to track merger benefits, outside counsel for UP provided the following examples of labor cost savings for 2001: \$17.6 million from train and engine crews; \$20.8 million from car repair; \$17.7 million from the marketing department; and \$29 million from the finance department. 
Labor protection/separation costs paid during the merger implementation period reportedly were subtracted from the labor savings on an as-paid basis. These expenditures, however, represent transfer payments from the railroad to employees and, as such, should not be subtracted from the real resource savings associated with the elimination of a redundant workforce. Their inclusion leads to an understatement of labor savings in an unknown amount. If the labor protection/separation projections of Table 1 are any guide, however, the understatement over a five-year merger implementation period would be almost $\$ 190$ million.

The "all other" savings in Table 4 reflect net savings from eliminating outsourcing of SP's computer systems and enhancing UP's systems (listed separately in Table 1 as communications/computers). It also reflects savings from combining headquarters functions in such areas as insurance, leases, warranties, and finance (which together appeared in general/administrative in Table 1). The commodity revenue entry in the table is not recognized here because it is the net revenue gains item that was rejected as a public benefit by the STB for reasons given above.

Recent academic research also suggests that rail mergers have produced efficiency gains. Wilson and Bitzan (2003) estimated a railroad cost function for the period 1983-1997 and then simulated industry costs to evaluate the changing industry structure. ${ }^{40}$ Their basic finding is that merger-related consolidation during the study period produced substantial cost savings. $\mathrm{UP} / \mathrm{SP}$ is one of eleven rail mergers studied and among the eight for which cost savings were observed.

The robustness of the Wilson and Bitzan finding for the UP/SP merger, however, is open to question because the only post-merger data included are for 1997. This was relatively early in the merger implementation plan and it was an unusual year because of the service disruptions. Wilson and Bitzan decomposed total merger-related cost changes into their sources - for UP/SP the predicted $\$ 137.8$ million in cost savings reflects certain cost-reducing factors (for example, lower output and reduced network size) outweighing certain cost-increasing factors (for example, lower average train speed). Lower output and train speed, however, may be symptomatic of the service disruptions and delays experienced in $1997 .{ }^{41}$ It would be desirable to add data to the study sample for additional years following the UP/SP merger to clarify the initial finding of costs savings for that rail merger.

Finally, if ongoing savings were increasing as Table 4 indicates, ceteris paribus, one would expect the combined firm's operating ratio to be declining during the post-merger period. In fact, the combined firm's operating ratio rose from $79.1 \%$ in 1996 to $87.4 \%$ in 1997 , and to $95.4 \%$ in 1998 before falling to $82.0 \%$ in $1999,82.3 \%$ in 2000 , and $80.7 \%$ in 2001 (UPC, 2001a, pp.22-23). Obviously the projected four point reduction in operating ratio was not

\footnotetext{
${ }^{40}$ Merger-related changes in railroad costs were simulated by comparing predicted post-merger costs of the combined railroad, using observed values for network/operating characteristics, factor prices, scale, and output, with the same post-merger cost function evaluated at the pre-merger values of the railroads' variables the year before they merged.

${ }^{41}$ As a rough comparison, one could compare the $\$ 137.8$ million figure (for 1997) with the merger applicants' claimed operating benefits for Year 1 (approximately 1997) of the five-year merger implementation plan. Table 1 above shows annual operating benefits (less net revenue gains) to be $\$ 217.0$ million (\$239.8 million minus $\$ 22.8$ million) for Year 1. As a projection, that figure does not include any ongoing cost impact of service problems actually experienced in 1997. Service disruption-related cost increases of a recurring nature would bring the $\$ 217$ million down closer to the $\$ 137.8$ million figure.
} 
achieved, but the impact of the merger on that ratio was obscured by other factors affecting operating revenues and operating expenses. Chief among these, as reported to the SEC, were the service problems of 1997-98 that decreased operating revenues and increased operating expenses. In its annual report to the SEC for 1999, UP management (UPRC, 1999, p.22) did credit increased operating efficiency and service levels and benefits of continuing integration of SP as a reason for operating expenses falling and the operating ratio improving. ${ }^{42}$ The operating ratio is also adversely affected by periods of significantly higher fuel costs, as was reported to be the case in $2000 .^{43}$

\subsection{Realization of unquantified benefits}

\subsubsection{Expanded single-line service and improved routings}

Regarding rail-network service improvements, UP reported during the 2001 STB oversight hearings that every shipper on the former UP system that did not already have SP as well as UP service, now has single-line service to every SP point (UPC-384, 2001, pp.33-34). Likewise, every shipper on the former SP system that did not already have UP service as well as SP service, now has single-line service to every UP point. Examples include (1) lumber from UP origins in WA and ID to SP points throughout CA, AZ, NM, and TX, and (2) grains from UP origins in IA, NE, and MN to AZ, and the San Joaquin and Imperial Valleys of CA.

Table 5 on the next page provides a number of examples of expanded single-line service and improved routings taken from an appendix to UP's submission for the 2001 oversight hearings. The examples indicate the merger-related changes giving rise to the service improvements and they identify the positive impact on the shippers affected. Elsewhere in UPC-384 (2001c, p.35), the implementation of directional operations is discussed, for example, pairing UP and SP lines from St. Louis and Memphis to the Rio Grande into more efficient directional railroads that save investment dollars and speed shipments. Public versions of these and other examples of service improvements were highlighted by UP in its presentations to financial analysts. ${ }^{44}$ Presumably these examples are verifiable and as such provide some confirmation for claimed merger efficiencies.

\footnotetext{
${ }^{42}$ Similarly, Conant (2004, p.129), attributes UP/SP's 1999 and 2000 financial recovery, from service disruptions and delays, to completion of merger-related capital investments in rail lines and acquisition of locomotives.

${ }^{43}$ Sun and Tang (2000) examined financial measures/operating performance, pre- and post-merger, for 13 rail mergers occurring in 1976-1996, including the UP/SP merger. One measure tested was operating margin, which can be shown to equal 1.0 minus the operating ratio. They found that operating performance declined (that is, operating ratio increased) during the first two years following a merger. The results for UP/SP were not stated separately but even if the outcome was the same, it would not be particularly surprising. First, the UP/SP service problems occurred during the first two post-merger years. Second, UP/SP merger implementation was intended to take more than two years.

${ }^{44}$ See, for example, King (2001). King conceded that some service improvements noted in the merger application had yet to be implemented, for example, single-line service through the mountain states linking Texas and the Pacific Northwest, and that directional operations had proved feasible so far only in the South Central region, as just noted.
} 
Amoco and Centennial Gas, LPG, 900 cars, UP Wyoming origins to Calexico CA (SP). Reduced rates on new single-line service allowed UP Wyoming LPG producers to market their product in western Mexico via SP's Calexico gateway on the border.

Anheuser Busch, malt, 940 cars, Idaho Falls ID (UP) to Van Nuys CA (SP). Traffic had been moving UPOgden-SP. UP reduced rates to reflect single-line service and a shorter route.

ARCH Coal, Inc., Canyon Fuels Co., and other Utah coal producers, coal, 33174 cars, Utah origins to Los Angeles for export. The merged system single-line route saves 470 miles over SP's pre-merger route. Rates have been reduced and traffic has grown substantially.

California Portland Cement, coal, 2,510 cars, Skyline UT (SP) to Colton (UP, SP) and Creal CA (SP). The merger created a new single-line route for this traffic more than 465 miles shorter than SP's previous route. UP reduced rates to Colton and to Creal to reflect its ability to move the traffic using the shorter route.

Chevron, petroleum oil, 200 cars, Port Allen LA (UP, KCS) to Richmond CA (SP, BN/SF). Before the merger, this traffic had been moving UP-Sweetwater TX-BN/SF. The merger made it possible for UP to offer new single-line service and capture this business at a lower rate than the previous joint-line rate.

Eastman Chemical, chemicals, 170 cars, Kingsport TN (NS) to San Pedro CA (SP, BN/SF). The traffic had been moving NS-BN/SF. UP was able to capture this traffic using its improved Southern Corridor route, which combines UP's line to El Paso with the former SP line to southern California.

Elf Atochem, caustic soda, 110 cars, TG Soda WY (UP) to American OR (BN/SF, SP). This traffic shifted from UP-Portland-BN/SF to UP direct and Elf Atochem saved on freight costs and enjoyed faster transit times as compared to the pre-merger joint-line route.

Great Western Malting, malt, 1300 cars, Vancouver WA (UP, BN/SF) to Fairfield (San Francisco Bay Area) (SP) and Van Nuys (Los Angeles Basin) (SP). After the merger, this traffic shifted from BN/SF-Portland-SP to UP direct, with its expanded single-line-service in the I-5 Corridor, at a savings to the customer.

Intermodal (trailer on flat car), Memphis-CA Corridor. New eastbound service was designed to attract United Parcel Service business from Los Angeles to Atlanta and Jacksonville with fifth-day service. Trains operate over UP lines in Arkansas and Texas and over SP's route from El Paso to Los Angeles, to form the shortest route.

Intermodal, Chicago-Northern California. Expedited service over the most direct combination of UP and SP routes through the Central Corridor.

Tyson, frozen poultry, 100 cars, Texarkana TX (SP) to Seattle WA (UP, BN/SF). This traffic shifted from SP$\mathrm{BN} / \mathrm{SF}$ to UP direct, with its expanded single-line service and a rate reduction per car.

Wheat from western Canada, 400 cars, Eastport WA (CP, UP) to various Arizona and California destinations (SP). As a result of the merger, the new single-line UP movement allows for more efficient operations and competitive rates.

Table 5: Examples of expanded single-line service and improved routings

Source: UPC-384 (2001b, Appendix A). 
More recently, amid an STB-imposed moratorium on rail mergers, railroads are reported by Machalaba (2001) to have entered into alliances as an alternative to end-to-end mergers to extend single-line service, thereby casting some doubt on the continuing necessity of ownership integration to achieve these efficiencies. UP itself is now on record asserting that many claimed benefits of recent end-to-end mergers (for example, BN/SF, UP/Missouri Pacific) might well have been achieved through means short of merger. ${ }^{45}$ UP gives as an example "long-term alliances to coordinate interline operations", made possible by rapid advances in information technology "to achieve benefits traditionally attributed to end-to-end mergers (UPC, 2000, p. 10)”. In fact, UP has sought to improve interline service by entering into such alliances with Canadian Pacific, Canadian National, CSX, and Norfolk Southern (King, 2001). The STB has declared in its new railroad consolidation procedures that it will consider more closely whether claimed benefits could be achieved by means other than the proposed merger before it. And it did find that initiatives such as "interline partnerships" can produce many of the efficiencies of a merger while risking less harm (STB, 2001b, p.16). The STB's action provides an additional incentive for potential merger partners to consider alternatives, although it is not a market-generated incentive.

\subsubsection{Increased capacity and capital investment}

UP ended up making about the capital expenditures it estimated. It had projected undertaking $\$ 1.3$ billion in capital expenditures to implement the operating plan for the merger. In the STB's 2000 oversight hearing decision (STB Oversight, 2000a, p.13), it is reported that by year-end UP would have spent about $\$ 1.25$ billion. This investment included almost $\$ 500$ million in rail line upgrades, more than $\$ 400$ million in capacity expansion projects, more than $\$ 100$ million in information technology, and almost $\$ 45$ million to refurbish SP locomotives. In UPC-384 (2001c, p.38) it is reported that by year-end UP would have spent $\$ 1.586$ billion related to the merger. While the amount actually invested was of the same order of magnitude initially projected, the project mix had changed. The projected $\$ 1.3$ billion figure was generated, to a significant extent, from a list of "essential projects" as viewed by SP prior to the merger. Many of these projects were undertaken but at a higher cost than SP had assumed (because SP had underestimated rehabilitation costs and/or projected traffic). For example, spending on SP's Sunset Route, listed in Table 2 above, was by 2001 up to nearly $\$ 275$ million and still growing as compared to the projected \$221.4 million; and the \$38.2 million projected for upgrading and rehabilitating SP's Roseville Yard ended up as more than \$140 million spent to completely rebuild the yard.

Other projects did not need to be undertaken because the merger provided alternatives apparently not considered at the time of the merger application. For example, the UP OKT Line listed in Table 2 was not upgraded (at a projected cost of $\$ 91.5$ million) because UP found a better route to upgrade (at a lower cost) for coal trains moving between Wyoming and Texas. Another example is the SP Mococo Line from Table 2, which did not need to be upgraded because a nearby UP line could be used and because of a change in traffic patterns.

\footnotetext{
${ }^{45}$ UP does not make this argument for parallel mergers, which is how it distinguishes the UP/SP merger. That merger according to UP, sought to improve service by eliminating redundancies in facilities and costs in geographic areas where overlaps existed. This is in contrast to an end-to-end merger's focus on geographic extensions of service.
} 
While the reallocation of capital expenditures may have led to greater or smaller efficiencies in some areas, as compared to projections in the merger application, it does not appear to have adversely affected the total level of operating benefits for a normal year. These were found by UP to be $\$ 679$ million (Table 4) as compared to UP's projection of $\$ 583.8$ million (Table 1) or to the STB's restatement of the projection as $\$ 534.3$ million (Table 3).

\subsection{Evidence on post-merger rail rates}

If ongoing savings were increasing as Table 4 indicates, and being passed on to shippers, one would expect to observe real rail rates to be declining in the West during the post-merger period. As early as the 1998 oversight hearings, the STB referred to confidential railroad submissions reportedly showing many examples of BN/SF winning 2-to-1 traffic from shippers and many examples of rate and service improvements by UP to retain such traffic. Rate reductions for 3-to-2 traffic were also said to be documented. In connection with the STB's annual oversight hearings, UP undertook a more systematic rate study which compared rail rates for key markets each year post-merger with those in a pre-merger period. ${ }^{46}$ In its July 2001 submission to the STB, UP reported, and the STB subsequently accepted, that UP rates had either fallen or remained the same in every relevant market over the multi-year period. ${ }^{47}$ This is confirmed by examination of the rate appendix to that submission, which was made available to the author, with UP's approval, by its outside attorneys. The rate comparisons cover 2-to-1 shippers (including and excluding the largest shipper in the Central Corridor), 3to-2 shippers (auto, intermodal, and general carload), and the following key commodities and traffic corridors: eastern Mexican gateway traffic, Utah and Colorado coal, GulfCoast plastics, other Gulf Coast chemicals and petroleum products, chemicals and petroleum products generally, and grain. For example, rates for Utah and Colorado Coal traffic held steady while those for traffic moving in the Houston-Memphis and Houston-New Orleans 2-to-1 corridors declined 10.3\% (UPC-384, 2001b, Appendix E-1).

UP measured rates in terms of revenue per ton-mile, using its internal revenue accounting database for the complete census of traffic, for purposes of the study, Revenue per ton-mile figures were adjusted for inflation and discounts. The study, however, does not attempt to control for any other factors that may have caused revenue per ton-mile to change over time (for example, productivity gains, changes in traffic mix, shipment characteristics, or input prices), so any conclusions about the direction and magnitude of rate changes should be viewed as tentative in nature.

STB staff also conducted a rate study (STB, 2000b); one that examines rate trends for rail traffic in the U.S. for the period 1984-99, using rates (revenue per ton-mile) for 15 commodity groups (farm products, coal, chemicals, lumber and wood, etc.), and separating rates for

\footnotetext{
46 The pre-merger period used as the benchmark for rate comparison purposes was October 1995 - March 1996. For the 2001 oversight hearings, for example, rates for October 2000 - March 2001 were compared to rates for October 1995 - March 1996.

${ }^{47}$ See STB Oversight (2001a, pp.3-4). According to STB Oversight (2000a), the Board had previously offered to make UP's traffic tapes available under seal to interested parties to verify or rebut the reported downward trend in rates. Although the rate study was available to outside counsel and consultants to parties to the proceedings, according to Covington \& Burling attorneys, the study was not challenged during the oversight proceedings.
} 
shipments originating in the West from those for shipments originating in the East. Data for the study come from the STB's non-public Carload Waybill Sample. The data show that inflationadjusted U.S. rail rates have fallen $45.3 \%$ since 1984 (48.8\% lower in the West and 40.7\% lower in the East). ${ }^{48}$ The STB attributes declining rates to productivity gains made in the aftermath of the 1980 Staggers Rail Act reforms that have been passed on to shippers. The study does not report rates for less aggregated commodity groups or for individual traffic lanes. It acknowledges that while average rail rates have fallen, not all rail customers have benefited equally. Certain individual rates have increased and not all sectors have enjoyed the same level of rate declines.

The STB points to one chart showing that western rates were stable from 1992 to 1994, then resumed their decline once the restructuring of the western rail network began. If one uses the STB data to focus on the consummation of the UP/SP merger in 1996, we see, as the STB points out, that inflation-adjusted revenue per ton-mile in the West declined $9.2 \%$ (as compared to a decline of $5.1 \%$ in the East). Rail rates declined in the West during this period for 13 of the 15 commodity groups tracked, suggesting that rail mergers were responsible for the decline. The STB study, however, has limitations in addition to not focusing on less aggregated commodity groups or individual traffic lanes. It does not attempt to explain, using econometric methods, the level of rail rates over time, nor does it attempt to isolate the impact of the UP/SP merger on rail rates from other factors. ${ }^{49}$

GAO undertook a study to examine the effects of the 1996 UP/SP merger on rail rates, apparently in response to concerns raised about the state of competition in the Central Corridor. GAO used a reduced form price (revenue per ton-mile) equation and a dummy variable to capture the impact of the merger. See GAO (2001). The pre-merger period was 1994-95 and the post-merger period was 1997-99. GAO focused on two geographic areas (Reno and Salt Lake City), both in the Central Corridor and both having high concentrations of potential 2-to-1 shippers. These two areas provided relatively clear examples of cases where BN/SF service substituted for SP service. The commodities considered were chemicals, coal, farm products, and non-metallic minerals. Six traffic movements were considered, for example, chemicals to the Reno area, coal from the Salt Lake City area. The other explanatory variables include cost and demand factors, a dummy for the period of service disruption and delay, a dummy for whether a rail car is railroad-owned (as opposed to shipper-owned), and a dummy for whether the rate reflects a contract rate. In addition, a dummy variable was included to capture the effect of BN/SF's presence as a competitor where otherwise the merger would have

\footnotetext{
${ }^{48}$ The STB used a Tornqvist Index in its calculations to correct for any changes in traffic mix, particularly any shift toward low revenue per ton-mile traffic. A revenue per ton measure of rates was also calculated and produced similar results to that using revenue per ton-mile, suggesting that any tendency toward longer hauls was not driving the results.

${ }^{49}$ Another rail rate-trends study, with similar results, was conducted more recently (GAO, 2002). It, too, is based on the Carload Waybill Sample and uses revenue per ton-mile to measure rates. As compared to the STB study, GAO focused on more traffic corridors but fewer, more aggregated, commodity groups. The study finds that rail rates generally declined nationwide and for many of the commodities and traffic corridors examined. Rail rates for some commodities and distances, however, remained stable or increased. The study did not compare rail rates in the West with those in the East, as the STB had done. GAO identified factors that could explain observed rate changes for specific commodities and corridors (including the presence or absence of rail-to-rail or intermodal competition) but cautioned that its explanations were not meant to be definitive. GAO did not attempt to link rate changes to the UP/SP merger in this study.
} 
created 2-to-1 shippers. ${ }^{50}$ Other factors, such as possible changes in the quality of service (aside from the service disruption period), were not incorporated. Nor did the data used to estimate the econometric model include a group of non-merging railroads (admittedly few in number in the West) to control for other changes during the time period under consideration.

$\mathrm{GAO}$ found that the merger by itself reduced rates for four (including coal) of the six commodity movements studied. For one commodity movement, post-merger rates were relatively unchanged (that is, the change was not statistically significant), while the remaining commodity movement (chemicals to the Reno area) experienced a merger-related rate increase. In GAO's words, the "UP/SP merger generally decreased rail rates, but not for all commodities and not for all shippers" (GAO, 2001, p.21). The coefficient for the dummy variable included to capture the extent of rail competition, that is, $\mathrm{BN} / \mathrm{SF}$ 's presence, was negative (indicating reduced rates) and statistically significant for one traffic movement, while rates were essentially unchanged for the other three movements. ${ }^{51} \mathrm{GAO}$ did not reach any conclusion about the merits of the UP/SP merger. It did recommend that econometric techniques be used in future STB oversight proceedings to better isolate the impact of mergers on rates.

UP reportedly identified some shortcomings to GAO's empirical work but decided not to comment publicly. In a briefing for the author, Covington \& Burling attorneys noted that some of the traffic examined was not representative. For example, the commodity movement for which rates increased involved a change in the composition of traffic from a lower-valued to a higher-valued chemical, the latter for which demand had increased. Also, according to outside counsel for UP, the GAO study did not withstand robustness tests UP staff performed on the estimation, that is, it gave unexpected results when applied to other traffic.

A modified version of GAO (2001) was subsequently published in the Journal of Regulatory Economics (Karikari et al., 2002). The data sources and method are basically the same, as is the model to be estimated econometrically, but the traffic movements tested differed and the authors chose to highlight the rate impact of the trackage rights granted to $\mathrm{BN} / \mathrm{SF}$ as a merger remedy. This version of the study excludes traffic movements involving Reno, and focuses on much higher volume movements of coal, chemicals, primary metals, farm products, petroleum, and food into or out of Salt Lake City (a total of eight traffic movements). The authors found that the merger by itself reduced rates for three commodities shipped from the area, and one commodity shipped to the area, remained essentially unchanged for three other movements, and increased for just one (chemicals to Salt Lake City). In addition, the coefficient for the dummy variable included to capture the competitive effect of $\mathrm{BN} / \mathrm{SF}$ 's presence was generally negative, indicating reduced rates. The latter finding is consistent with BN/SF being a more effective competitor post-merger than SP was pre-merger. The authors conclude that the trackage rights remedy for potential 2-to-1 shippers was effective.

In addition to rate studies directly related to STB's oversight hearings, Park et al. (2001) have used simulation methods to estimate the competitive effects of the BN/SF (Burlington Northern merged with Santa Fe in 1995) and UP/SP mergers on grain shipments from various

\footnotetext{
${ }^{50}$ Data were from the STB Carload Waybill Sample and the regression model was estimated using the SAS SURVEYREG procedure because the data are from stratified samples.

${ }^{51}$ Coal was excluded from this aspect of the analysis because of the absence of potential 2-to-1 shippers in the Salt Lake City and Reno areas.
} 
subregions of Kansas to Houston, for export. The researchers make use of a transportation cost-minimizing algorithm to derive least-cost wheat movements (based on data from the ICC Rail Costing Program) and a profit improvement algorithm to evaluate each railroad's ability to raise rates (Nash equilibrium prices) above variable costs. Oligopoly interaction is assumed to be characterized by price-setting behavior in a homogeneous goods industry. Mergers are simulated by dropping the restriction that railroads cannot interchange traffic and by eliminating interchange charges between merging railroads. The result, in some instances, is that the merger leads to a more direct routing of traffic, which is cost reducing. The simulations also assume the combined railroad adopts the cost structure of the lower cost merger partner. The major finding of the study is that the mergers resulted in negligible changes in market power for shipments from Kansas origins. The STB's measure of market power - the ratio of revenue to variable cost - was used for that purpose. ${ }^{52}$ The authors conclude that a railroad's ability to raise rates is restricted if shippers can turn to at least one other railroad for freight service.

In conclusion, the rate reduction data submitted by UP during the course of the oversight proceedings, and the rate study conducted by STB staff were generally consistent with the UP/SP merger having a pro-competitive effect and meeting even a consumer welfare standard. Neither GAO (2001) nor Park et al. (2001), each of which is narrowly focused on certain traffic segments, undercuts those findings. The UP and STB studies are not definitive, however, because they do not isolate the impact of the merger from other factors, including productivity gains, that could explain rate reductions. Nor was the STB staff study performed at a disaggregated level with respect to commodities and traffic corridors. With those caveats in mind, the UP rate study and STB staff study showing rate declines post-merger are also consistent with merger cost savings and efficiencies being realized and passed on to shippers in the form of lower rates.

\subsection{Conclusions on realized merger benefits and policy implications}

Implementation of the merger plan in 1997 and 1998 was overshadowed by the service problems that affected UP/SP system-wide. Despite the prevailing conventional wisdom, the service problems were caused by a number of factors - not just management mistakes in implementing the merger - and the serious problems were overcome by the fall of 1998. STB oversight hearings, particularly toward the end of the five-year implementation period, suggest that substantial merger efficiencies (public benefits) were being achieved, but this is a preliminary finding based on the public record of the hearings.

Additional documentation of the realization of quantified benefits is provided by UP's internal tracking of merger efficiencies achieved. That reporting shows ongoing benefits increasing during the merger implementation period, being realized in the areas contemplated by the operating plan, and exceeding projected amounts. Recent academic research also suggests that rail mergers, including UP/SP, have produced efficiency gains, although the study result for UP/SP should be viewed as tentative. Further confirmation of UP/SP merger

\footnotetext{
${ }^{52}$ UP's revenue to variable cost ratios declined marginally for shipments from two Kansas subregions while they increased $8.4 \%$ and $1.9 \%$ for shipments from the other two Kansas subregions. UP's (and BN/SF's) resulting revenue to variable cost ratios for all four subregions were considered quite modest - at most 1.1 relative to the fixed costs that also need to be covered.
} 
efficiencies would have been provided by evidence of a declining operating ratio, as predicted in the merger application, but other factors - particularly the service problems of 1997-98 obscured this relationship. Rail merger benefits were expected to take the form of expanded single-line service and improved routings, and UP's confidential submission for the 2001 oversight hearings provided numerous examples of that happening. UP also made representations to securities analysts that it was realizing service improvements of these types. Another development consistent with the achievement of substantial merger efficiencies was that planned capital expenditures, which were a prerequisite for obtaining cost savings and efficiencies, were undertaken, albeit in a form somewhat modified from that in the operating plan.

Indirect evidence that significant merger efficiencies were achieved would include evidence of rate reductions, post-merger. Available rate evidence from public and non-public sources, while not definitive, was generally consistent with merger cost savings and efficiencies being realized and being passed on to shippers in the form of lower rates.

Thus, available evidence indicates that UP has documented the realization of substantial merger efficiencies of the types claimed (although they are not adjusted for any merger-related costs from the 1997-98 service problems). Many of these were public in nature and mergerspecific, that is, attributable to the merger of two rail networks (not just to industry-wide productivity gains), and not reasonably achieved at that time through means short of merger. Admittedly, much of the evidence on realized merger efficiencies comes from UP itself and it was not closely scrutinized by the STB during its oversight hearings. Nonetheless, there are reasons for treating these claims as plausible. First, the realization of quantified benefits was tracked in considerable detail for management purposes, which made the benefits verifiable and subject to challenge by those in UP management with the incentive to obtain accurate and unbiased information. Second, the nature of unquantified benefits realized is what would be expected from a merger of rail networks with parallel and end-to-end elements, and their detailed enumeration makes them verifiable. Third, available evidence on rate reductions in the post-merger period is consistent with the realization of merger efficiencies that are passed on to shippers.

Although lessons from a single case study of a consummated railroad merger are limited, a number of implications for rail merger policy, and merger policy more generally, are evident. The findings from the case study do suggest that skepticism about merger-related efficiency claims may be overdone. Skepticism may be particularly inappropriate in a context where, as here, redundancies between merging parties seem prevalent, alternatives to merger appear limited, the parties have identified and documented efficiencies beforehand as part of a merger planning process, and they have a record of tracking efficiencies as part of a merger implementation plan. In these circumstances, the odds should improve that some efficiency claims meet regulatory standards and perhaps antitrust standards, that is, are merger-specific, verifiable, and likely to be realized. Of course, the network configurations in this case happen to involve a mix of significant parallel elements and end-to-end components. Other rail mergers (or network mergers in other industries) with differing degrees of network utilization, overlap, and/or complementarities are likely to generate a different mix and magnitude of potential efficiencies and need to be evaluated on a case-by-case basis. Given the incentive for applicants to exaggerate merger benefits to win approval, it is important for a regulatory or 
antitrust agency to have in place a verification system. Antitrust agencies currently have procedures to directly verify claimed merger benefits and the STB has appropriately indicated its intention to scrutinize such benefits more closely. ${ }^{53}$

A broader point is that the UP/SP case study illustrates the value of regulatory/antitrust agencies (as well as researchers) doing retrospective studies of merger outcomes. This merger was approved despite predictions of anticompetitive effects (notwithstanding the remedies conditioning that approval) and heavy discounting of claimed merger benefits. Nevertheless, available post-merger evidence suggests significant efficiencies were achieved and passed on to shippers in the form of lower rates and enhanced service. Admittedly, efficiency claims are by nature prospective and, even if unbiased, uncertain. Likewise, predictions that a merger will create or enhance market power and thereby lead to a price increase are imprecise. This is true with respect to antitrust merger reviews as well despite significant advances in the past ten years in data availability, quantitative techniques, and the modeling of competitive behavior as part of merger investigations. It follows that the assessment and weighing of a proposed merger's potential harm and potential benefit will be subject to some degree of regulatory/enforcement error. On occasion a merger will be allowed that is harmful and a merger will be blocked that is welfare enhancing. Retrospective studies of prices and efficiencies can assist agencies in reducing their error rates and should be considered a "best practice".

It is worth noting what progress has been made along these lines. Although the STB did not pay particular attention to the realization of claimed benefits for the UP/SP merger as part of its post-merger oversight hearings, it has more recently established a formal oversight process to determine, among other things, whether the "merger benefit projections accepted by the Board are being realized in a timely manner" (STB, 2001, p.38). Relatedly, the STB had considered evidence on rates as part of its UP/SP post-merger oversight but was criticized, and appropriately so, for focusing on the overall magnitude and direction of rate changes and not adequately isolating the impact of the merger on rates (GAO, 2001, p.3-4). GAO has recommended that econometric techniques be used to isolate merger effects and the STB has indicated that it is amenable to that approach, despite some reservations about its precision and reliability and the burdens it might place on the relevant parties (GAO, 2001, pp.27-28).

Retrospective studies have been given consideration by antitrust agencies as well. The FTC, for example, made the following commitment, for program evaluation purposes, under the Government Performance and Results Act (GPRA):

"Evaluate effectiveness of FTC merger policy by conducting retrospective studies of FTC enforcement actions, or decisions not to take enforcement action, to determine if actual outcomes were consistent with the goals the Commission sought to achieve. ${ }^{.54}$

Examples of such studies include hospital merger (Vita and Sacher, 2001) and petroleum merger (Taylor and Hosken, 2004) retrospectives. The lessons learned can improve the ability to evaluate prospective mergers that are before regulatory/antitrust agencies.

\footnotetext{
${ }^{53}$ STB (2001b, p.17). The STB's revised rail consolidation procedures also require applicants to identify additional measures for use in the event that the promised benefits "fail to materialize in a timely manner" (STB, 2001, p.22). This provision is intended to hold applicants accountable for their merger benefit claims, and thereby provide a disincentive to exaggerate, but its exact meaning and impact remain untested.

${ }^{54}$ FTC (2003, p.28).
} 


\section{$5 \quad$ References}

Ainsworth, D.P. (1995) Verified Statement on behalf of Union Pacific Corporation and Southern Pacific Corporation in UP/SP-22, "Railroad Merger Application," 1: 433-463, November 30, in Union Pacific Corp. - Control \& Merger - Southern Pacific Corp., STB Finance Docket 32760.

Berndt, E.R., A.F. Friedlaender, J.S.-E.W. Chang, and C.A. Vellturo (1993) "Cost Effects of Mergers and Deregulation in the U.S. Rail Industry," The Journal of Productivity Analysis, 4: 127-144.

Chapin, A. and S. Schmidt (1999) "Do Mergers Improve Efficiency? Evidence from Deregulated Rail Freight," Journal of Transport Economics and Policy 33: 147-162.

Christensen, L.R. (1996) Verified Statement on behalf of the U.S. Department of Justice in DOJ-8, redacted version, April 9, in Union Pacific Corp. - Control \& Merger - Southern Pacific Corp., STB Finance Docket 32760.

Commissioner Owen (1996) Commenting, Surface Transportation Board, Union Pacific/Southern Pacific Merger, 1 STB 233.

Conant, M. (2004) Railroad Bankruptcies and Mergers from Chicago West: 1975-2001: Financial Analysis and Regulatory Critique. Research in Transportation Economics, Vol. 7. Elsevier JAI: Amsterdam.

Conrath, C.W., and N.A. Widnell (1999) "Efficiency Claims in Merger Analysis: Hostility or Humility?” George Mason Law Review, 7: 685-705.

Draper, M.J. and D.W. Salzman (1995) Verified Statement on behalf of Union Pacific Corporation and Southern Pacific Corporation in UP/SP-22, "Railroad Merger Application," 1: 361-370, November 30, in Union Pacific Corp. - Control \& Merger - Southern Pacific Corp., STB Finance Docket 32760.

Ellig, J. (2002) "Railroad Deregulation and Consumer Welfare," Journal of Regulatory Economics, 21: 143-167.

Federal Trade Commission (2003) "Performance Plan: Fiscal Year 2003 Through Fiscal 2004," http://www.ftc.gov/opp/grpa/ppfy03fy04.pdf.

Gray, J.T. (2001) Verified Statement on behalf of Union Pacific Corporation in UP/SP-384, "Union Pacific's Fifth Annual Oversight Report," public version, July 2, in Union Pacific Corp. - Control \& Merger - Southern Pacific Corp., STB Finance Docket 32760.

Grimm, C.M. and J.J. Plaistow (1999) "Competitive Effects of Railroad Mergers," Transportation Research Forum, 38: 65-78. 
Harper, D.V. (1982) Transportation in America: Users, Carriers, Government. Prentice Hall: Englewood Cliffs, N.J.

Kaplan, P. (1997) “Grappling with Gridlock,” Washington Times, December 3: B7.

Karikari, J.A., S.M. Brown, and M. Hadji (2002) "The Union Pacific/Southern Pacific Railroads Merger: Effect of Trackage Rights on Rates," Journal of Regulatory Economics, 22: 271-285.

King, B. (2001) "Network Optimization," Presentation by Union Pacific Executive Vice President to Securities Analysts, New York City, November 28-29.

Kolasky, W. (2004) "Prepared Remarks for Panel on Efficiencies/Dynamic Analysis/Integrated Analysis," FTC/DOJ Joint Workshop on Merger Enforcement, Washington, D.C., February 1719. http://www.ftc.gov/bc/mergerenforce/presentations/040219kolasky.pdf

Kolasky, W.J. and A.R. Dick (2003) "The Merger Guidelines and the Integration of Efficiencies into Antitrust Review of Horizontal Mergers," Antitrust Law Journal, 71: 207251.

Kwoka, Jr. J.E. and L.J. White (2004) "Manifest Destiny? The Union Pacific and Southern Pacific Railroad Merger (1996)," in J.E. Kwoka, Jr. \& L.J. White (eds.) The Antitrust Revolution: Economics, Competition, and Policy. New York: Oxford University Press.

McFarland, H.B. (1999) “The Union Pacific-Southern Pacific Merger: What Can Be Learned?” The Transportation Antitrust Update, 5-10.

Machalaba, D. (2001) "Railroads Are Entering Alliances in Effort to Increase Efficiency," Wall Street Journal, May 24.

Massa, S. (1997) "Are All Railroad Mergers in the Public Interest? An Analysis of the Union Pacific Merger with Southern Pacific,” Transportation Law Journal, 24: 413-442.

Park, J.J., M.W. Babcock, K. Lemke, and D.L. Weisman (2001) "Simulating the Effects of Railroad Mergers," Southern Economic Journal, 67: 938-953.

Pittman, R. (1990) "Railroads and Competition: The Santa Fe/Southern Pacific Merger Proposal," Journal of Industrial Economics, 39: 25-45.

Pittman, R. (1998) “Train Wreck: A Lesson in Megamergers,” mimeo, June 1.

Roberts, P.O., Transmode Consultants (1995) Verified Statement on behalf of Union Pacific Corporation and Southern Pacific Corporation in UP/SP-22, "Railroad Merger Application," 1: 
465-485, November 30, in Union Pacific Corp. - Control \& Merger-Southern Pacific Corp., STB Finance Docket 32760.

Sun, H.-L. and A.P. Tang (2000) "The Sources of Railroad Merger Gains: Evidence from Stock Price Reaction and Operating Performance,” Transportation Journal, 39: 14-26.

Surface Transportation Board (1996) Union Pacific/Southern Pacific Merger, 1 STB 233.

Surface Transportation Board (1997) “Oversight," Decision No. 10, in Union Pacific Corp. Control \& Merger - Southern Pacific Corp., STB Finance Docket 32760 (Sub-No. 21), Decision served October 27.

Surface Transportation Board (1998a) "General Oversight," Decision No. 13, in Union Pacific Corp. - Control \& Merger - Southern Pacific Corp., STB Finance Docket 32760 (Sub-No. 21), Decision served December 21.

Surface Transportation Board (1998b) "Houston/Gulf Coast Oversight," Decision No., 10 in Union Pacific Corp. - Control \& Merger - Southern Pacific Corp., STB Finance Docket 32760 (Sub-No. 26), Decision served December 21.

Surface Transportation Board (1998c) “Joint Petition for Further Service Order," STB Service Order No. 1518, Decision served February 17.

Surface Transportation Board (1998d) "Joint Petition for Further Service Order," STB Service Order No. 1518 (Sub-No. 1), Decision served July 31.

Surface Transportation Board (1999) “General Oversight," Decision No. 15, in Union Pacific Corp. - Control \& Merger - Southern Pacific Corp., STB Finance Docket 32760 (Sub-No. 21), Decision served November 30.

Surface Transportation Board (2000a) "General Oversight," Decision No. 16, in Union Pacific Corp. - Control \& Merger - Southern Pacific Corp., STB Finance Docket 32760 (Sub-No. 21), Decision served December 15.

Surface Transportation Board (2000b) "Rail Rates Continue Multi-Year Decline," Report of the Office of Economics, Environmental Analysis, and Administration.

Surface Transportation Board (2001a) “General Oversight," Decision No. 21 in Union Pacific Corp. - Control \& Merger - Southern Pacific Corp., STB Finance Docket 32760 (Sub-No. 21), Decision served December 20.

Surface Transportation Board (2001b) Major Rail Consolidation Procedures, STB Ex Parte No. 582 (Sub-No. 1), Decision served June 11. 
Taylor, C.T. and D.S. Hosken (2004) "The Economic Effects of the Marathon - Ashland Joint Venture: The Importance of Industry Supply Shocks and Vertical Market Structure,' Bureau of Economics Working Paper No. 270, Federal Trade Commission.

Union Pacific Corporation (2000) Comments of Union Pacific Corporation and Union Pacific Railroad Company Before the Surface Transportation Board, in Public Views of Major Rail Consolidations, STB Ex Parte No. 582, February 29.

Union Pacific Corporation (2001a) Annual Report.

Union Pacific Corporation (2001b) UP/SP-384, "Union Pacific's Fifth Annual Oversight Report," confidential version, July 2, in Union Pacific Corp. - Control \& Merger - Southern Pacific Corp., STB Finance Docket 32760.

Union Pacific Corporation (2001c) UP/SP-384, "Union Pacific's Fifth Annual Oversight Report," public version, July 2, in Union Pacific Corp. - Control \& Merger - Southern Pacific Corp., STB Finance Docket 32760.

Union Pacific Corporation and Southern Pacific Corporation (1995a) UP/SP-22, "Railroad Merger Application," November 30, Vol. 1, in Union Pacific Corp. - Control \& Merger Southern Pacific Corp., STB Finance Docket 32760.

Union Pacific Corporation and Southern Pacific Corporation (1995b) UP/SP-24, "Railroad Merger Application," November 30, Vol. 3, in Union Pacific Corp. - Control \& Merger Southern Pacific Corp., STB Finance Docket 32760.

Union Pacific Railroad Company (1997) "Annual Report to the Securities and Exchange Commission," Form 10-K for fiscal year ended December 31.

Union Pacific Railroad Company (1999) "Annual Report to the Securities and Exchange Commission," Form 10-K for fiscal year ending December 31.

Union Pacific Railroad Company (undated-a). "Closing the Gap: Customer Satisfaction (19982000)," Company document.

Union Pacific Railroad Company (undated-b). "Merger Benefits and Costs: Ongoing Merger Benefits," Company document.

Union Pacific Railroad Company (1998) "Quarterly Report to the Securities and Exchange Commission," Form 10-Q for the quarter ending June 30.

U.S. Department of Justice (1996) Brief Before the Surface Transportation Board, redacted version, June 3, DOJ-14 in Union Pacific Corp. - Control \& Merger-Southern Pacific Corp., STB Finance Docket 32760. 
U.S. Department of Justice and Federal Trade Commission (1992) Horizontal Merger Guidelines.

U.S. General Accounting Office (2001) "Freight Railroad Regulation: Surface Transportation Board's Oversight Could Benefit From Evidence Better Identifying How Mergers Affect Rates," (GAO-01-689), Report to the Chairman, Subcommittee on Transportation and Related Agencies, Committee on Appropriations, House of Representatives.

U.S. General Accounting Office (2002) "Railroad Regulation: Changes in Freight Railroad Rates from 1997 through 2000," (GAO-02-524), Report to the Chairman, Committee on Transportation and Infrastructure, House of Representatives.

Vita, M.G. and S. Sacher (2001) "The Competitive Effects of Not-for-Profit Hospital Mergers: A Case Study," Journal of Industrial Economics, 49: 63-84.

White, L.J. (2002) "Staples-Office Depot and UP-SP: An Antitrust Tale of Two Proposed Mergers," in Daniel J. Slottje (eds.), Measuring Market Power. Contributions to Economic Analysis, Vol. 255. Elsevier Science: North-Holland, Amsterdam.

Wilson, W. and J. Bitzan (2003) "Industry Costs and Consolidation: Efficiency Gains and Mergers in the Railroad Industry," MPC Report No. 03-145, Upper Great Plains Transportation Institute.

Yarberry, L.C. (1995) Verified Statement on behalf of Union Pacific Corporation and Southern Pacific Corporation in UP/SP-22, "Railroad Merger Application," 1: 251-289, November 30, in Union Pacific Corp. - Control \& Merger - Southern Pacific Corp., STB Finance Docket 32760 . 